\title{
Alzheimer's disease: recent concepts on the relation of mitochondrial disturbances, excitotoxicity, neuroinflammation, and kynurenines
}

Authors: Dénes Zádoria, Gábor Veres ${ }^{\mathrm{a}}$, Levente Szalárdy ${ }^{\mathrm{a}}$, Péter Klivényi ${ }^{\mathrm{a}}$, László Vécsei ${ }^{\mathrm{a}, \mathrm{b}}$

\section{Affiliations:}

${ }^{a}$ Department of Neurology, Faculty of Medicine, Albert Szent-Györgyi Clinical Center, University of Szeged, Semmelweis u. 6, H-6725 Szeged, Hungary

${ }^{\mathrm{b}}$ MTA-SZTE Neuroscience Research Group, Semmelweis u. 6, H-6725 Szeged, Hungary

\section{Running title:}

Kynurenines in Alzheimer's disease

\section{Corresponding author:}

László Vécsei MD, PhD, DSc

Department of Neurology, Faculty of Medicine, Albert Szent-Györgyi Clinical Center, University of Szeged,

Semmelweis u. 6, H-6725 Szeged, Hungary

Phone: +36(62)545351; Fax: +36(62)545597

E-mail: vecsei.laszlo@med.u-szeged.hu

Co-authors’emails: zadori.denes@med.u-szeged.hu, veresg.gytk@gmail.com, szalardy.levente@med.u-szeged.hu, klivenyi.peter@med.u-szeged.hu 


\section{ABSTRACT}

The pathomechanism of Alzheimer's disease (AD) certainly involves mitochondrial disturbances, glutamate excitotoxicity, and neuroinflammation. The three main aspects of mitochondrial dysfunction in $\mathrm{AD}$, i.e., the defects in dynamics, altered bioenergetics, and the deficient transport act synergistically. In addition, glutamatergic neurotransmission is affected in several ways. The balance between synaptic and extrasynaptic glutamatergic transmission is shifted toward the extrasynaptic site contributing to glutamate excitotoxicity, a phenomenon augmented by increased glutamate release and decreased glutamate uptake. Neuroinflammation in $\mathrm{AD}$ is predominantly linked to central players of the innate immune system, with central nervous system (CNS)-resident microglia, astroglia, and perivascular macrophages having been implicated at the cellular level. Several abnormalities have been described regarding the activation of certain steps of the kynurenine $(\mathrm{KYN})$ pathway of tryptophan metabolism in AD. First of all, the activation of indolamine 2,3-dioxygenase, the first and rate-limiting step of the pathway, is well-demonstrated. 3-Hydroxy-L-KYN and its metabolite, 3-hydroxy-anthranilic acid have pro-oxidant, antioxidant, and potent immunomodulatory features, giving relevance to their alterations in AD. Another metabolite, quinolinic acid, has been demonstrated to be neurotoxic, promoting glutamate excitotoxicity, reactive oxygen species production, lipid peroxidation, and microglial neuroinflammation, and its abundant presence in $\mathrm{AD}$ pathologies has been demonstrated. Finally, the neuroprotective metabolite, kynurenic acid, has been associated with antagonistic effects at glutamate receptors, free radical scavenging, and immunomodulation, giving rise to potential therapeutic implications. This review presents the multiple connections of KYN pathwayrelated alterations to three main domains of $\mathrm{AD}$ pathomechanism, such as mitochondrial dysfunction, excitotoxicity, and neuroinflammation, implicating possible therapeutic options. 
Keywords: Alzheimer's disease, mitochondrial dysfunction, glutamate excitotoxicity, neuroinflammation, tryptophan metabolism, kynurenine pathway, kynurenic acid, 3-hydroxyL-kynurenine, quinolinic acid 


\section{INTRODUCTION}

Alzheimer's disease (AD) is the most prevalent progressive neurodegenerative disorder, characterized by age-related memory impairments and personality changes, placing a significant burden not only on the families and caregivers, but on the global economy as well [1]. As a result of the great scientific effort which was made to reveal the complex pathomechanism of $\mathrm{AD}$, the deleterious factors responsible for disease development are becoming better understood [2]. However, currently only symptomatic therapies are available for this insidious condition, and there is at present no curative treatment available [3]. Accordingly, there is a huge need for the identification of novel therapeutic targets via which a better symptomatic or causative care may be provided beside the more widely applied preventive measures. A number of hypotheses exist with regard to the pathogenesis of AD. In addition to the probably most popular amyloid cascade and tau hypotheses, some alternative ones, such as those related to DNA damage, aberrant neuronal cell cycle reentry, and demyelination, have been elaborated to explain certain discrepancies in the current models and the serial failure of clinical trials assessing drugs targeting amyloidor tau-induced alterations, and to try to fill the remaining gaps [4]. However, the pathological hallmarks currently applied to establish the definite diagnosis of AD during autopsies are amyloid plaques and neurofibrillary tangles, keeping in mind that the exact initiating factor in AD pathogenesis still remains unknown. Despite the mostly unknown initiating factor, downstream mitochondrial disturbances, glutamate excitotoxicity, and neuroinflammation serve as probably the most important linking points in neurodegenerative disorders, being demonstrated in human and experimental studies in AD as well, in addition to the distinguishing proteinopathic features of neurodegenerative conditions. Some metabolites and enzymes of the kynurenine (KYN) 
pathway of tryptophan (TRP) metabolism have come into focus of recent research with regard to these three cardinal aspects of neurodegeneration [5].

The aim of this review is to highlight some aspects of mitochondrial disturbances, glutamate excitotoxicity, and neuroinflammation and their relations to the multiple documented alterations of the KYN pathway of the TRP metabolism (Fig. 1) in AD and its experimental models, with the delineation of some possible therapeutic targets, without attempting an indepth analysis of current leading and alternative hypotheses of $\mathrm{AD}$, an effort exceeding the scope of this current paper.

\section{MITOCHONDRIAL DISTURBANCES IN ALZHEIMER'S DISEASE}

There are three main aspects of mitochondrial dysfunction in AD: 1) defects in mitochondrial fission/fusion (i.e., dynamics); 2, altered mitochondrial bioenergetics; and 3) defects in mitochondrial transport [6-8].

Mitochondrial dynamics is a process consisting of fusion (a moving mitochondrion interacts with a passive one forming a tubular network) and consecutive fission (a segmentation resulting in two mitochondria) $[9,10]$. Fusion is mediated by mitochondrial inner membrane GTPases optic atrophy 1 (Opa1) and mitofusin 1 and 2 (Mfn1 and Mfn2), whereas fission is regulated by mitochondrial outer membrane division proteins dynamin-related protein 1 (Drp1) and mitochondrial fission protein 1 (Fis1) amongst others. The analysis of brain samples of AD patients demonstrated fragmented and punctuated mitochondrial morphology resulting from dysfunctional mitochondrial dynamics [11, 12]. Accordingly, the mRNA levels of Fis1 were increased, whereas those of Opa1, Mfn1, Mfn2, and surprisingly Drp1 were decreased in AD brains [13]. In vitro studies, where M17 or N2a cells overexpressing the wild-type amyloid-beta $(A \beta)$ precursor protein $(\mathrm{A} \beta \mathrm{PP})$ or that of comprising the Swedish mutation $\left(\mathrm{A} \beta \mathrm{PP} \mathrm{P}^{\mathrm{sw}}\right)$ were applied, demonstrated that $\mathrm{A} \beta$ accumulation resulted in decreased 
Mfn1, Mfn2 and Opa1, whereas Fis1 levels were increased, accompanied with the fragmentation of mitochondria and reduction in their number $[12,14]$. Alterations in the level of Drp1 are controversial, because it was demonstrated to be unchanged or interestingly decreased $[12,14]$. The fragmentation of mitochondria was also confirmed in neuronal cell cultures obtained from a transgenic (Tg2576) mouse model of $\mathrm{AD}$, where Fis1 gene and protein were significantly upregulated, whereas $M f n 1$ gene and protein were decreased [15]. Furthermore, the application of oligomeric A $\beta$-derived diffusible ligands (ADDL) induced the decrease of mitochondrial length and reduced mitochondrial density in neurites and axons via the impairment of their bidirectional transport [16-18]. The underlying reason for $A \beta$-induced mitochondrial alterations may be the presence of direct interaction of $\mathrm{A} \beta$ aggregates with these organelles, followed by their accumulation related to translocase of outer membrane 40 (TOM40) and translocase of inner membrane 23 (TIM23) [19-21]. This pathological A $\beta$ accumulation blocks the import of cytoplasmic proteins into the mitochondria, interfering with their functionality, and its extent was linked to the degree of cognitive impairment of AD $[21,22]$. One aspect of this impaired functionality may be the interaction of A $\beta$ with Drp1 [23]. In a mouse model of $A D$, the observed association of $A \beta$ with synaptic mitochondria may serve as one of the culprits for synaptic degeneration characteristic of AD [18]. In addition to $\mathrm{A} \beta$-related impairment in mitochondrial dynamics, tau may also have a pathological influence on it $[24,25]$. Accordingly, the co-localization of hyperphosphorylated tau protein with Drp1 was demonstrated as well with the presence of excessive mitochondrial fragmentation [26].

In addition to its effect on mitochondrial dynamics, the binding of $A \beta$ to the mitochondria results in deficient energy production as well, considerably contributing to the pathogenesis of $\mathrm{AD}[27,28]$. The assessment of mitochondria isolated from brain specimens of AD patients demonstrated the reduced activity of cytochrome c oxidase (i.e., complex IV of the electron 
transport chain (ETC)) and ATP synthase (i.e., complex V of the ETC), with a compensatory increased expression of the corresponding genes [29-33]. Furthermore, the reduced activity of key mitochondrial matrix enzymes, such as pyruvate dehydrogenase and $\alpha$-ketoglutarate dehydrogenase was demonstrated as well [34-36]. The presence of alterations in mitochondrial bioenergetics was clearly detected in in vitro or in vivo models overexpressing $\mathrm{A} \beta \mathrm{PP}$ or $\mathrm{A} \beta \mathrm{PP}^{\mathrm{sw}}$ with or without mutations in the presenilin 1 (PS1) or presenilin 2 (PS2) or tau genes [12, 27, 37-47]. In addition to enzymatic dysfunction, oxidative stress-induced damage of mitochondrial DNA (mtDNA) is pronounced as well, and accordingly, the post mortem analysis of the brains of $\mathrm{AD}$ patients demonstrated increased rate of mtDNA mutations and decreased mtDNA copy number [48-51]. The exposure of mitochondria to different $A \beta$ species and their accumulation resulted in impaired activity of the ETC with a consequent decrease in respiration rates and mitochondrial membrane potential and an increase in reactive oxygen species (ROS) production [39, 52-56]. The pathological interactions involve the inhibition of $A \beta$-binding alcohol dehydrogenase (ABAD), the decrease of the threshold of mitochondrial permeability transition pore (mPTP) formation by cyclophilin D, and the increased conductivity of the voltage-dependent anion-selective channel 1 as well, thereby considerably contributing to the further worsening of mitochondrial dysfunction [57-59]. The presence of apoptosis-related events (e.g., mitochondrial swelling, opening of the mPTP, cytochrome c release, and caspase-3 activation) was demonstrated as well [60-63]. The A $\beta$-induced ROS production may evoke a vicious cycle via the further enhancing $A \beta$ formation $[45,64]$. ROS generation resulted in the upregulation of beta-site amyloid precursor protein cleaving enzyme 1 (BACE1) activity and expression level, thereby increasing $A \beta$ load [65-67]. Beside the deleterious effects of $A \beta$, the pathological forms of tau induce the disturbance of mitochondrial bioenergetics as well. Studies with cell lines or transgenic animals overexpressing mutant tau protein demonstrated mitochondrial 
depolarization, impaired respiration, reduced ATP synthesis, increased oxidative stress, and lipid peroxidation $[25,27,41,44,47,68,69]$. Interestingly, mitochondrial energy disturbances probably precede $A \beta$-related pathology [27, 43]. In light of proteomic analyses, these abnormalities may be related to the alterations of complexes I and IV of the ETC; the impairment of the former one was related to tau, whereas the impairment of the latter one was related to $\mathrm{A} \beta$ [27]. This second aspect of mitochondrial disturbance in $\mathrm{AD}$ accompanies to synaptic dysfunction as well, as preserved bioenergetics are essential for the following functions: 1) the maintenance of ion gradients required for sustained membrane potential; 2) the mobilization and release of synaptic vesicles; and 3) the support of synaptic assembly and plasticity [8].

The presence of $A P O E \& 4$ genotype has been demonstrated to be associated with a considerably (i.e., four times) enhanced likelihood for the development of $\mathrm{AD}$ [70]. APOE $\varepsilon 4$ contributes to the pathogenic processes by disrupting neurogenesis, cholesterol metabolism, $\mathrm{A} \beta \mathrm{PP}$ processing, the degradation of $\mathrm{A} \beta$, tau hyperphosphorylation, and other cellular pathways, including mitochondrial function and synaptic plasticity [70-73]. The decreased activity of $\alpha$-ketoglutarate dehydrogenase in AD brain correlates with APOE $\varepsilon 4$ genotype and it decreases the expression of complex I and IV and the activity of complex IV of the ETC as well $[74,75]$. This impairment is presumably mediated by the interaction of $A P O E \varepsilon 4$ with mitochondria $[75,76]$.

The transport of mitochondria is mediated by fast axonal transport [77]. Kinesin-1 heavy chain protein, encoded by the $K I F 5 B$ gene is responsible for the anterograde transport of mitochondria with the aid of adaptors (trafficking kinesin-binding protein 1 and 2; Trak1 and Trak2) to mitochondrial Rho GTPase 1 and 2 (Miro1 and Miro2), whereas dynein protein performs their retrograde transport via the interaction with the dynactin complex [78]. The treatment of rodent hippocampal neurons with A $\beta$ or the presence of a PS1 or A $\beta$ PP mutation 
resulted in the significant reduction of anterograde mitochondrial transport, thereby considerably accompanying to synaptic dysfunction characteristic of $\mathrm{AD}$, which findings were confirmed in mouse model of $\mathrm{AD}$ and by the post mortem analysis of brains from $\mathrm{AD}$ patients $[15,79-86]$. It was hypothesized that alterations in synaptic mitochondria develops earlier than in non-synaptic mitochondria [87]. It seems that tau is required for $A \beta$-induced impairment of axonal transport, which process is presumably initiated via the activation of NMDARs, glycogen synthase kinase $3 \beta(\mathrm{GSK} 3 \beta)$, and casein kinase 2 (CK2) $[84,88,89]$. Naturally, the above detailed three main aspects of mitochondrial dysfunction act synergistically: the activation of Drp1 and Fis1 by free radicals resulted in mitochondrial fragmentation, their altered synaptic transport, and consequentially reduced synaptic ATP levels and dysfunction [87]. Furthermore, in light of the downregulation of peroxisome proliferator-activated receptor gamma (PPAR $\gamma)$ coactivator 1-alpha (PGC-1 $\alpha)$ and its target genes, the mitochondrial biogenesis signaling has been indicated to be impaired as well in AD $[90,91]$

\section{GLUTAMATE EXCITOTOXICITY IN ALZHEIMER'S DISEASE}

Beside and in part in connection with mitochondrial dysfunction, $\mathrm{A} \beta$ can influence glutamatergic neurotransmission in several ways. Under physiological concentrations, A $\beta$ takes part in the regulation of proper neurotransmitter release; however, the elevated concentrations of $\mathrm{A} \beta$ alters synaptic transmission via its deteriorating effects on synaptic vesicle pools $[92,93]$. With regard to its effects on glutamatergic neurotransmitter receptors, the NMDAR may be the major site of $A \beta$ action even in the early stages of $A D$; and furthermore, NMDAR activation increase the production of $A \beta$ [94]. The composition of a conventional NMDAR is composed of two glycine or D-serine-binding GluN1 subunits, which are responsible for the formation of the ion channel, and two glutamate-binding GluN2 
(A-D) subunits, having regulatory and refining roles. The available data suggest that the predominance of GluN2A subunit-containing NMDARs at the synaptic site promotes neuronal survival, involving the activation cyclic-AMP response element binding protein (CREB) and the suppression of forehead box protein O (FOXO)-mediated pathways [95-99]. Contrastingly, the predominance of GluN2B subunit-containing NMDARs at the extrasynaptic site, increased by the phosphorylation at Tyr1336 site, mediates neurotoxicity involving the opposite effects on the above mentioned pathways [95-99]. However, in light of some recent findings, the simultaneous activation of synaptic NMDARs may be also necessary for the initiation of cell death program [100]. So in brief, alterations in synaptic and extrasynaptic glutamatergic transmissions seem to synergistically contribute to the pathomechanism of $\mathrm{AD}$. The alterations induced by oligomeric $\mathrm{A} \beta$ contributing to synaptic dysfunction involve the decrease of long-term potentiation (LTP; a form of synaptic strengthening following a brief, high-frequency stimulation), the enhancement of long-term depression (LTD; a form of synaptic weakening following low-frequency stimulation or synaptic inactivity), and the depotentiation of LTP [101-104]. The enhancement of LTD in $\mathrm{AD}$ is mediated by the internalization of synaptic $\alpha$-amino-3-hydroxy-5-methyl-4isoxazolepropionic acid (AMPA) and NMDA receptors induced by oligomeric A $\beta$ and nonapoptotic caspase activation $[62,105,106]$. In vitro studies suggest that the activation NMDARs by $A \beta$ is mainly confined to those containing GluN2B subunit, i.e., with a preferential localization at the extrasynaptic site [107]. Furthermore, the experimental intracerebroventricular injection of $\mathrm{A} \beta$ in rats downregulated the ratio of GluN2A/GluN2B subunits, shifting the pathways toward excitotoxicity [99]. Some of the deleterious downstream excitotoxic effects of $\mathrm{A} \beta$ via the GluN2B subunit-containing NMDARs is mediated by the connection of the receptors to neuronal nitric oxide (NO) synthase (NOS) by a scaffolding protein PSD-95 (postsynaptic density protein of molecular weight $95 \mathrm{kDa}$ ), 
thereby increasing the production of NO in an excessive amount [108-110]. The above mentioned increase in the production of $A \beta$ via extrasynaptic NMDAR activation is probably mediated by the shift of A $\beta$ PP production from A $\beta$ PP695 to Kunitz protease inhibitory domain-containing isoforms with higher amyloidogenic potential and leads to the formation of a vicious cycle $[111,112]$. GluN2B-mediated glutamatergic neurotransmission seems to be involved in tau-induced neurotoxicity as well, probably via the tyrosine kinase Fyn pathway $[113,114]$. Tau increased targeting of Fyn sensitizes NMDARs to A $\beta$ toxicity with a positive feedback, i.e., the A $\beta$-triggered hyperphosphorylation of tau enhance its affinity for Fyn [115]. The major downstream pathological effect evoked by $\mathrm{A} \beta$ in this way may be the disturbance of neuronal calcium homeostasis [116].

In addition to its receptorial effects, $A \beta$ downregulates glutamate uptake capacity of astrocytes and thereby induces a dysfunctional glutamate clearance from the extracellular space [117-120]. Indeed, soluble A $\beta$ oligomers were proved to be capable of inducing glutamate release from astrocytes [121]. The downregulation of the expression of excitatory amino acid transporter 2, one of the transporters responsible for glutamate uptake by astrocytes, was demonstrated in transgenic mouse models as well [122, 123]. However, the available data on human specimens with regard to this issue are controversial [124-127]. Additionally, some findings indicate that microglial upregulation of cystine/glutamate antiporter system $\mathrm{x}_{\mathrm{c}}^{-}$may also contribute to altered glutamate homeostasis [128]. The consequentially elevated glutamate levels in the extracellular space and the above delineated presence of energy impairment, as a consequence of mitochondrial dysfunction and oxidative stress, may interact to cause glutamate excitotoxicity, involving a partial membrane depolarization, which results in the relief of the $\mathrm{Mg}^{2+}$ blockade of the NMDAR channel and leads to subsequent calcium overload of the cell [129]. 


\section{NEUROINFLAMMATION IN ALZHEIMER'S DISEASE}

Emerging evidence supports that neuroinflammation, i.e., the active presence of proinflammatory immunological processes within the CNS, contributes substantially to the pathogenesis of a number of neurodegenerative disorders, including $\mathrm{AD}$, and is probably more relevant in terms of the pathogenesis as core neuropathological hallmarks of the disease [130]. Signs indicative of ongoing neuroinflammation during the course may be present before the dementia stage, opening possibilities for the identification of putative prognostic biomarkers as well as of potential therapeutic targets of the disease.

Pathogenic markers of neuroinflammation in AD include cellular and soluble factors as well. As compared with encephalitides and multiple sclerosis (MS) where the adaptive immune system with target-specific $\mathrm{T}$ and B lymphocytes are presumed to play key roles in disease pathogenesis (including the promotion of the degenerative alterations), neuroinflammation in neurodegenerative disorders including $\mathrm{AD}$ are predominantly linked to central players of the innate immune system, with CNS-resident microglia, astroglia, and perivascular macrophages having been heavily implicated at the cellular level [131]. This neuropathological dichotomy is reflected also by the findings of recent genome-wide association studies (GWASs) and an expression quantitative trait locus (eQTL) genetic study [132].

Microglia are resident myeloid cells of the CNS that, similarly to tissue macrophages, are responsible for screening their respective tissue region for pathogens and cellular debris in order to engage them in part via phagocytosis and degradation [133]. Furthermore, these cells are also involved in the development and maintenance of neuronal circuitry in part by releasing trophic factors such as brain-derived neurotrophic factor (BDNF) $[134,135]$. There is a plethora of evidence for the crucial contribution of microglia to $\mathrm{AD}$ pathogenesis. Microglia are long known to be abundantly present around senile A $\beta$ plaques in post mortem AD brain tissues [136]. These cells are phenotypically altered, suggestive of being reactive to 
pathological stimuli. This increased microglial activation in the human brain with probable $\mathrm{AD}$ can now be reflected also by non-invasive imaging techniques taking advantage of radiotracers (such as microglial translocator protein (TSPO) ligands) used with positron emission tomography $[137,138]$. Evidence suggests that brain parenchymal A $\beta$ (especially in monomeric form) is capable of priming and thus aiding the activation of microglia in response to pathological stimuli, which in turn produce and release a number of proinflammatory cytokines and chemokines [131, 139-141]. This process is presumed to be aggravated by additional environmental and genetic components such as systemic inflammation and mutations affecting the innate immune system, respectively [131]. Though the in vivo relevance of microglial phagocytosis of $\mathrm{A} \beta$ is a matter of debate, microglia are known to express intra- and extracellular $A \beta$ degrading enzymes (e.g., neprilysin and insulindegrading enzyme, respectively), and their normal function plays crucial roles in the clearance of parenchymal $\mathrm{A} \beta$ from the brain, most probably as part of a self-limiting adaptive process $[142,143]$. The sustained presence of $\mathrm{A} \beta$ in the brain, however (especially in more aggregated forms, such as oligomers, protofibrils, and fibrils), is presumed to lead to permanent neuroinflammation with a chronic activation of microglia through various receptor-dependent and -independent mechanisms, which is accompanied by different microglial phenotypic alterations and deficient microglial function in a self-sustaining process, supposedly contributing to neurodegeneration and the development tau pathology in the $\mathrm{AD}$ brain [131]. In line with this concept, deficient microglial function has been demonstrated in transgenic $\mathrm{AD}$ mice, whereas mutations affecting genes involved in microglial phagocytosis and function, including TREM2, CD33, MS4A6A, and CR1, have been associated with an increased risk of sporadic $\mathrm{AD}$, and the levels of the autophagy protein Beclin 1, with crucial roles in microglial phagocytosis, have been shown to be decreased in microglia isolated from brains of sporadic AD patients [144-154]. Though the applicability of 
the 'proinflammatory M1' versus 'anti-inflammatory M2' dichotomous phenotypical classification of macrophages for CNS-resident microglia is extensively debated, agonists of PPAR $\gamma$, a transcription factor that drives anti-inflammatory processes including a switch toward an M2 phenotype and whose relevance is of increasing interest in MS as well, are under extensive preclinical and clinical investigation as potential disease-modifying therapies in $\mathrm{AD}$, with a phase 3 trial called TOMORROW currently ongoing with the PPAR $\gamma$ agonist, pioglitazone [131, 155-160].

Astroglia, a resident cell-type of the CNS of neurodectodermal origin, has been strongly implicated in the pathogenesis of $\mathrm{AD}$, though the information at present available about its exact roles in the pathogenesis is substantially less comprehensive than about those of microglia. Similarly to microglia, reactive astrocytes surround and engage A $\beta$ senile plaques, contributing to neuroinflammation via releasing cytokines, chemokines, and nitric oxide [130, 161-163]. Just like microglia, astrocytes express intra- and extracellular A $\beta$-degrading enzymatic apparatus upon exposure to $A \beta$ [164]. Furthermore, they also internalize and degrade $\mathrm{A} \beta$, with astroglial ApoE playing crucial roles in both astroglia- and microgliamediated $A \beta$ clearance among experimental conditions [165-168]. Supporting a potential detrimental role of astrocytes upon chronic activation during AD pathogenesis, viral inactivation of astrocytes alleviated the pathology in a transgenic murine model of AD [169]. The potential roles of other cell types in the CNS in the modulation of neuroinflammation in $\mathrm{AD}$, including those of perivascular macrophages, endothelial cells, neurons, and oligodendrocytes, are also under investigation, but the results are at present far less conclusive compared to those for microglia and astrocytes [131].

Alterations indicative of ongoing neuroinflammation in $\mathrm{AD}$ can be detected at the level of soluble macromolecules as well. The expression of a number of proinflammatory cytokines, major sources of which are astrocytes and microglia, have been revealed in human AD brains, 
as well as in the brains of transgenic rodent $\mathrm{AD}$ models [170-181]. The most frequently reported cytokines include tumor necrosis factor alpha (TNF $\alpha$ ), interleukin (IL)-1 $\beta$, IL-6, IL12, and IL-23 among many others. The possible biomarker value of the cerebrospinal fluid (CSF) or plasma levels of some of these cytokines have also been proposed in AD; however, the reports are extremely heterogeneous, which at present do not enable firm conclusions to be reached [182]. More intriguingly, the levels of some of the cytokines found elevated in the CSF of AD patients by some authors have also been reported to be increased even before the dementia phase of $\mathrm{AD}$, i.e., during the stage of mild cognitive impairment (MCI) [182]. In particular, elevated levels of the proinflammatory cytokine, TNF $\alpha$, and its soluble receptors, sTNFR1 and sTNFR2, in the CSF of patients with MCI were reported to predict more rapid conversion to AD dementia [183, 184]. Though these types of 'conversion studies' are associated with severe inherent limitations, they substantiate the potential diagnostic relevance of neuroinflammatory cytokine alterations in AD [185]. Despite the proposed and increasingly established roles of proinflammatory cytokine alterations in disease pathogenesis in $\mathrm{AD}$, controversial results have also been published demonstrating deleterious effects of anti-inflammatory cytokines and beneficial effects of proinflammatory cytokines in terms of brain A $\beta$ clearance in vivo [186-190]. Of note, generally disappointing results have been obtained from studies aiming at the modification of inflammatory response in AD with nonsteroidal anti-inflammatory drugs (NSAIDs) or elective cyclooxygenase-2 (COX-2) inhibitors at the clinical level [191-195]. These molecules in part aim at reducing the production of the inflammatory arachidonate metabolite prostaglandin E2, the level of which was likewise found altered in the CSF of AD patients and whose microglial receptorial action appears to be crucial in the development of core pathological features in $\mathrm{AD}$ animal models, whereas another presumed mechanism of action of NSAIDs is related to the activation of PPAR $\gamma$ [196200]. All these underlie the relevance of the double-edged nature of neuroinflammation in AD 
and neurodegenerative conditions as a whole, a maladaptive chronification of an originally beneficial acute immune response, the suppression of which may result in adverse outcomes, and the exploitation of the therapeutic potential of which will definitely require further research and more sophisticated therapeutic approaches.

\section{THE RELATION OF KYNURENINES TO MITOCHONDRIAL DYSFUNCTION,} GLUTAMATE EXCITOTOXICITY, AND NEUROINFLAMMATION, AND THEIR INVOLVEMENT IN THE PATHOGENESIS OF ALZHEIMER'S DISEASE Approximately 95\% of TRP is metabolized through its KYN pathway (Fig. 1) [201]. This metabolic route consists of several neuroactive compounds, including kynurenic acid (KYNA), 3-hydroxy-L-KYN (3-OH-L-KYN), 3-hydroxyanthranilic acid (3-OHANA), and quinolinic acid (QUIN). The detailed description of their physiological functions together with a historical overview of research on these metabolites have already been published, and are, accordingly, out of the scope of this current review [202]. Briefly, this pathway is predominantly responsible for the endogenous production of nicotinamide adenine dinucleotide, and is capable of influencing redox reactions and glutamatergic neurotransmission through its neuroactive intermediates, often in opposite directions. Although some other metabolites of the pathway may also have effects on neuronal function and dysfunction (especially in terms of redox reactions), their role in neuronal physiology and pathophysiology is at present less firmly established and are probably less important compared to the 'neuroactive' compounds [203]. A sustained balance between the concentrations of neuroactive intermediates of the KYN pathway may help to ensure the maintenance of normal neural function. By contrast, a number of abnormalities have been described as regards the activation of certain steps of the KYN pathway of TRP metabolism in various tissues and CNS regions in 
neurodegenerative disorders, including AD (Figs. 2 and 3) [5, 202, 204-207]. Accordingly, therapeutic options may arise either via the application of drug analogs or via the modulation of the activity of their producing enzymes [5, 208-211].

\section{Indolamine 2,3-dioxygenase}

As regards the first and rate-limiting step of the pathway, a number of studies described increased activity of indolamine 2,3-dioxygenase (IDO) in AD [212-215]. A group demonstrating increased activity of IDO in the serum of AD patient reported an inverse correlation of IDO activity with cognitive performance, accompanied by a positive correlations with the levels of neopterin, a macrophage activity marker, as well as soluble receptors for TNF and IL-2 [212, 213]. Others reported increased IDO immunoreactivity in microglia, astrocytes, and neurons, with the glial expression of IDO being the highest surrounding senile plaques [214]. The preferential accumulation of IDO in senile plaques as well as neurofibrillary tangles have later been confirmed by another group as well [216]. In line with these results and the proposed ability of $A \beta$ to activate microglia in $A D$ brains, increased IDO expression has been demonstrated in microglia and human primary macrophages in vitro upon exposure to $A \beta_{1-42}$ [217]. These together indicate that the inflammatory milieu in $\mathrm{AD}$, including elevated concentrations of $\mathrm{TNF} \alpha$, a potent activator of IDO, promotes the activation of TRP metabolism via the KYN pathway, leading to the production of multiple downstream effectors with various potential consequences relevant in terms of the pathogenesis of $\mathrm{AD}$, as discussed below.

\section{3-Hydroxy-L-kynurenine and 3-hydroxyanthranilic acid}

According to some early studies, the proposed deleterious effects of 3-OH-L-KYN, a metabolite produced by kynurenine 3-monooxygenase (KMO), are mediated by free radicals 
and not glutamate receptors, and some of its detrimental actions may be due to its metabolite, 3-OH-ANA, via its auto-oxidation, leading to the production of superoxide anion [218-221]. In contrast, there is a body of evidence calling for antioxidant and free radical scavenging properties inherent to 3-OH-L-KYN as well; therefore, a dual action in the CNS may be proposed in this respect [222]. Indeed, in studies on striatal slices, 3-OH-L-KYN exerted a concentration- and time-dependent dual effect on lipid peroxidation, inducing pro-oxidant actions at low $(5-20 \mu \mathrm{M})$ and antioxidant activity at higher $(100 \mu \mathrm{M})$ micromolar concentrations [223]. The proposed protective actions were related to the stimulation of glutathione S-transferase and superoxide dismutase activities and to the elevations in the protein contents of the transcription factor and antioxidant regulator nuclear factor (erythroidderived 2)-like 2 (Nrf2) and some of its related proteins [223]. It is important to mention that the basal extracellular concentrations of $3-\mathrm{OH}-\mathrm{L}-\mathrm{KYN}$ in the rat brain $(2 \mathrm{nM})$ are far below the above mentioned levels [224]. A recent study assessing the effects of 3-OH-L-KYN and 3-OH-ANA with regard to mitochondrial dysfunction demonstrated that both compounds decreased 3-(4,5-dimethylthiazol-2-yl)-2,5-diphenyltetrazolium bromide (MTT) reduction in a concentration-dependent manner in association with an impairment of mitochondrial membrane potential [225]. However, these findings were not related to alterations in ROS production or lipid peroxidation, probably due to the demonstrated hydroxyl radical and peroxynitrite scavenging activities of both compounds [225]. Summarily, the concentrationand time-dependent toxic effects of 3-OH-L-KYN and 3-OH-ANA include the impairment of cellular energy metabolism, but the accompanying role of early ROS production is controversial. Nevertheless, these findings demonstrate that the KMO branch of the kynurenine pathway, i.e., which gives rise to the metabolites 3-OH-L-KYN and 3-OH-ANA among others, may represent a direct relationship between neuroinflammation and oxidative stress/mitochondrial dysfunction in $\mathrm{AD}$, as this branch is preferentially active in 
microglia/macrophages, which respond with IDO overexpression and subsequently increased KYN metabolism upon exposure to $A \beta[217,226-229]$.

With regard to the levels of these metabolites in AD tissues, though early studies demonstrated non-significant alterations in 3-OH-L-KYN levels in AD brains, recent immunohistochemical studies proved that $3-\mathrm{OH}-\mathrm{L}-\mathrm{KYN}$ may considerably accompany to the damage of neuronal tissues, with its levels found to be significantly elevated in hippocampal neurons in AD compared to controls [216, 230, 231]. With regard to the periphery, markedly increased levels of 3-OH-L-KYN [232] as well as elevated levels of circulating IgA directed against 3-OH-L-KYN [233] were found in serum samples of AD patients, though a study found only a trend for 3-OH-L-KYN to be increased in the plasma of AD patients [234]. This elevation in the periphery may at least in part underlie the elevated concentrations of 3-OH-LKYN and its metabolite QUIN in AD brain tissues, as 3-OH-L-KYN can pass through the $\mathrm{BBB}$ via an active transport. In contrast, the CSF content of 3-OH-L-KYN in AD patients was found decreased by $81 \%$ [235].

The potential alteration of 3-OH-L-KYN and 3-OH-ANA levels in the brain may also be relevant in terms of neuroinflammation in $\mathrm{AD}$, since both molecules have been associated with potent immunosuppressive features, as being among the most potent effectors of IDOmediated endogenous immunosuppression, an effect relevant in immunological phenomena such as allograft acceptance, tumor camouflage, and maternofetal tolerance [5]. Of note, these effects are generally attributed to the suppression of target-specific immunity, especially of Th1/Th17 cell proliferation, which is a response rather characteristic of MS than of AD where natural immunity is presumed to take leading roles. However, a recent report revealed that infiltrating Th1 and Th17 cells are present in the brain of transgenic AD mice (A $\beta P P / P S 1)$, and that $A \beta$-specific Th1 cells transferred to these murine brains could elicit marked microglial activation, A $\beta$ deposition, and cognitive dysfunction [236]. Similar lymphocytic 
engagement of deposited $A \beta$ can be seen in a clinical and pathological subtype of cerebral $A \beta$ angiopathy (CAA) in humans, that is CAA-related inflammation (CAA-RI) [237]. These findings indicate the potential role of target-specific immunity as well in the early events of $\mathrm{AD}$ pathogenesis, giving further potential relevance of altered 3-OH-L-KYN and 3-OH-ANA levels in the brain of AD patients. On the other hand, this potentially relevant feature further complicates the interpretation of the possible roles of these molecules in AD, especially of 3OH-L-KYN, a molecule that has pro-oxidant, antioxidant, as well as potent immunomodulatory features, all being of plausible relevance in AD.

\section{Quinolinic acid}

QUIN, which is produced by 3-hydroxyanthranilate 3,4-dioxygenase (HAAO), is a weak but specific competitive agonist of the NMDAR subgroup containing the GluN2A and GluN2B subunits, with low receptor affinity [238]. QUIN has been demonstrated to be a neurotoxic compound in several paradigms $[5,210]$. On the one hand, it can cause glutamate excitotoxicity via the following mechanisms: it can directly activate NMDARs and, in addition to its receptorial effect, it is capable of modulating glutamate release and inhibiting the uptake of glutamate by astrocytes [239-241]. Accordingly, the hyperphosphorylation of tau proteins via the overactivation of NMDAR is augmented by QUIN, further contributing to glutamate excitotoxicity in AD [242]. On the other hand, QUIN has been demonstrated to be involved in ROS production and lipid peroxidation as well, in an NMDAR-dependent or independent manner, thereby further contributing to the pathogenesis of AD [243-246]. QUIN is capable of inducing NOS activity in astrocytes and neurons, generating ROS via the formation of QUIN-Fe ${ }^{2+}$ complexes, and reducing antioxidant defenses, thereby leading to oxidative stress and diminished mitochondrial function [247-252]. 
As regards the expression of QUIN in AD brains, early studies demonstrated no alterations in various regions of the brain of AD patients [253-255]. However, Guillemin et al. reported increased QUIN immunoreactivity in neurons and glial cells in AD brains, with the microglial expression being the highest surrounding senile plaques, but also uniformly labeling neurofibrillary tangles, which is in line with the ability of QUIN to increase tau hyperphosphorylation $[214,215]$. This increase of QUIN in AD plaques have been confirmed by further quantitative methods by the same group [256]. This increase corresponds to elevated QUIN levels observed in the plasma of AD patients correlating inversely with cognitive functions [234]. However, this finding as regards increased blood QUIN levels in AD could not be replicated by others from serum [232]. Likewise, no difference could be detected in the CSF levels of QUIN by multiple groups [255, 257]. Data regarding the potential of QUIN to contribute to IDO-mediated immunosuppression is contradictory [258260]. Contrastingly, QUIN has been shown to promote astrocytes to produce large amounts of the potent monocyte chemoattractant protein-1 (MCP-1), and has the ability to induce astroglial production of IL-1 $\beta$ (a key mediator of neuroinflammation in AD), and dosedependently promotes astroglial proliferation, dysfunction, or cell death [261-263]. Together with the data evidencing that QUIN is preferentially expressed in microglia/macrophages and also does so in AD brains, these data may indicate that QUIN does not only represent a direct link between microglial neuroinflammation and oxidative damage/NMDAR-mediated excitotoxicity/mitochondrial dysfunction as relevant pathogenic factors in $\mathrm{AD}$, but it may serve as a direct mediator of a positive feedback loop in microglial neuroinflammation [214, 226-229]. With regard to the therapeutic targeting of QUIN-related alterations in AD, the application of 4-chlorokynurenine (4-Cl-KYN), the BBB-penetrant pro-drug of the selective glycine site NMDAR antagonist, 7-Cl-kynurenic acid (7-Cl-KYNA), was demonstrated to ameliorate QUIN-induced hippocampal toxicity [264]. The explanation for this finding may 
involve the powerful inhibition of QUIN synthesis by 4-chloro-3-hydroxyanthranilate, another metabolite of 4-Cl-KYN, in addition to the formation of 7-Cl-KYNA [265, 266].

\section{Kynurenic acid}

KYNA is another product of the KYN pathway of TRP metabolism. It is produced by kynurenine aminotransferases (KATs) and can influence glutamatergic neurotransmission at several levels and have exerted neuroprotective effects in several paradigms [5, 202, 210, 267, 268]. KYNA is capable of exerting a wide-spectrum of endogenous antagonistic effects at ionotropic excitatory amino acid receptors [269]. Its major action related to such receptors is mediated via the strychnine-insensitive glycine-binding site on the GluN1 subunit of the NMDAR [270]. However, the basal extracellular concentration of KYNA in rats (15-23 nM) is far below the required level, i.e., $\sim 10-20 \mu \mathrm{M}$ concentrations, to directly interfere with NMDAR functions under physiological concentrations [208, 271, 272]. Of note, KYNA has been demonstrated to have a dose-dependent dual action on AMPA receptors, as in low (nM to $\mu \mathrm{M}$ ) concentrations, KYNA is capable of facilitating AMPA receptor responses with a potential positive effect on LTP, whereas in higher concentrations it has inhibitory effects, which may interfere with LTP formation and may be associated with cognitive dysfunctions $[273,274]$. Though the most widely recognized and generally hypothesized neuroprotective mechanism of KYNA is linked to its anti-glutamatergic effects, predominantly on NMDARs, recent experimental findings associate KYNA with various additional actions counteracting processes relevant in mitochondrial dysfunction and neuroinflammation involved in AD.

The connection between altered KYNA levels and mitochondrial dysfunction is represented by the following observations. 1) As a free radical scavenger, KYNA can be regarded as an endogenous neuroprotectant in conditions with mitochondrial dysfunction, where excessive free radical production is present as a general feature [275- 
277]. 2) Its potent NMDAR inhibitor functions can indirectly alleviate the downstream deleterious effects of excitotoxicity on mitochondrial function (i.e., by decreasing intracellular $\mathrm{Ca}^{2+}$ overload) [278]. 3) The expression/function of KATs has been reported to be downregulated in models/conditions with mitochondrial dysfunction [279, 280].

The effects of KYNA with direct implications in neuroinflammation in AD include the inhibition of TNFa expression via an agonistic effect on orphan receptor GPR35 on monocytes, and more recently by increasing the expression of neprilysin, an A $\beta$-degrading metallopeptidase expressed by astrocytes and microglia, the proper function of which has been found to substantially influence the severity of AD-like phenotype in experimental models in vivo [277, 281-284]. Regarding the proposed A $\beta$-degrading effect, however, it is to be mentioned that a previous study did not found KYNA to be able to modulate A $\beta$ aggregation in their experiments [285]. In terms of immunomodulation, although KYNA did not influence A $\beta$-induced cell death in BV-2 microglial cell culture, it exerted an antiinflammatory action by means of the reduction of the levels of proinflammatory cytokines TNF $\alpha$ and IL-6, and, intriguingly, decreasing the phagocytosis of A $\beta$ [286]. As regards IL-6, another study likewise found a downregulation of this cytokine in stimulated mast cells [287]. However, a study on MCF-7 breast tumor cells reported the ability of KYNA to promote of IL-6 expression/secretion by activating aryl hydrocarbon receptor (AhR), which the authors discussed to potentially contribute to tumor camouflage by leading to a consequent increase in IDO expression in dendritic cells with various immunosuppressive downstream effects [288]. The relevance or presence of this mechanism in a neurodegenerative/neuroinflammatory setting in the brain, however, has not been established.

With regard to post mortem analyses of the brains of AD patients, the levels of KYNA were found to be non-significantly elevated in the hippocampus with no apparent changes in the 
activities of either KAT-I or KAT-II [231]. Consistently, no significant alterations in KYNA levels in various brain regions were detected by another group in AD brains [289]. However, increased KAT-I activity in the caudate nucleus and putamen (together with a non-significant alterations in KAT-II activity) with a consequent significant elevations in KYNA concentrations in the respective regions have been described [231]. The role and relevance of this phenomenon in the striatum are of question, but the presence of a compensatory mechanism against the pronounced degeneration of the corticostriatal pathway with increased glutamate binding in the striatum in AD may be a suitable explanation [290, 291]. The cellular distribution of the observed alterations in KAT activity and/or expression may have a special importance, because it was demonstrated that treatment of rats with sodium azide (an inhibitor of mitochondrial complex IV) altered the pattern of the expression of KAT-I in various relevant brain regions: the astroglial immunoreactivity was found to be decreased, whereas neurons started to express KAT-I [292]. With regard to the alterations of KYNA levels in human biological fluids with a possible biomarker value, decreased concentrations have been detected in the serum, plasma, and CSF of AD patients; however, recent studies have reported unaltered serum and CSF KYNA levels [232, 234, 257, 293, 294]. In one of these recent studies that did not find significant alteration in CSF KYNA level between AD patients and age-matched controls and revealed no associations between CSF KYNA level and cognitive dysfunctions in AD patients, CSF KYNA levels were, however, found to be significantly correlated with the AD-biomarker p-tau (hyperphosphorylated tau) and the inflammatory marker soluble intercellular adhesion molecule-1 [294]. Furthermore, a gender difference was also demonstrated in this study, i.e., female AD patients had significantly higher CSF KYNA levels compared to the males, a difference not revealed in the control group. Interestingly, however, increased levels of circulating immunoglobulin A (IgA) against 
conjugated KYNA were detected in the serum of AD patients, adding to the spectrum of controversial findings in the field [233].

On the basis of the well-established contribution of glutamate excitotoxicity (including the elevation of hippocampal QUIN levels), mitochondrial dysfunction (including ROS accumulation), and neuroinflammation (including glial IDO activation) to AD pathogenesis, the accumulating data supports that KYNA has multiple potential beneficial actions that involve all these three major pathogenic domains. Indeed, the inclusion of KYNA during the preparation process of hippocampal slices from $\mathrm{A} \beta \mathrm{PP}^{\mathrm{sw}}$ transgenic animals exerted an agedependent protective effect against the development of altered synaptic transmission, presumably by limiting the extent of excitotoxicity [295]. Furthermore, the systemic administration of L-KYN (the common precursor of KYNA, the probably neurotoxic metabolites 3-OH-L-KYN and anthranilic acid (ANA), and the 'proglutamatergic' excitotoxin QUIN) together with probenecid (an organic acid transporter inhibitor targeting the mechanisms eliminating KYNA from the brain) exerted protective effects against the intrahippocampal administration of $\mathrm{A} \beta_{25-35}$, with a significant improvement in spatial memory. This effect was most probably attributed to NMDAR inhibition, as demonstrated by comparable effect of the specific NMDAR inhibitor, MK-801 [296]. A possible way to enhance the bioavailability of KYNA may be achieved by its improved transport through the blood-brain barrier (BBB) via its pharmaceutical modulation [297]. Most recently, the neuroprotective effect of a novel BBB-permeable KYNA analog with multiple pharmacological actions relevant in $\mathrm{AD}$ pathogenesis, including NMDAR binding, free radical scavenging, and also interference with $A \beta$ fibril evolution, has been reported in a Caenorhabditis elegans model of AD [298]. The potential neuroprotective/immunomodulatory features of KYNA relevant in AD highlight the importance of astrocytes in $\mathrm{AD}$ pathogenesis, as they lack functional KMO therefore 
preferentially metabolizing L-KYN toward KYNA, and they readily expressed IDO in AD hippocampi [214, 228]. Interestingly, another KYNA analog, 5,7-dichlorokynurenic acid with a preferential action at the glycine-binding site of the NMDAR, was unable to recapitulate the protective effect of memantine, a partial antagonist at the NMDAR channel, on the abnormal hyperphosphorylation and accumulation of tau in organotypic cultures of rat hippocampal slices [299].

Despite the promising experimental data, manipulations resulting in elevated levels of KYNA in the brain may inherently harbor effects associated with cognitive impairments and behavioral alterations [300-306]. Accordingly, knocking out one of its producing enzyme (KAT-II) resulted in the improvement of cognitive functions in mice [305]. Of note, achieving a selective inhibition of GluN2B subunit-containing extrasynaptic NMDARs may be a successful strategy in the amelioration of neurodegenerative processes [307]. Indeed, reaching an extracellular concentration that is capable of inhibiting the tonic extrasynaptic NMDAR currents and thereby reducing glutamate excitotoxicity in AD without impairing synaptic glutamatergic neurotransmission may yield a possible therapeutic option [308]. KYNA amides are synthesized by the amidation of KYNA at the carboxyl moiety and the resulting substances may preferentially act on GluN2B subunit-containing extrasynaptic NMDARs [209, 309]. Accordingly, one of the KYNA amide compounds synthesized by our group, N-(2-N,N-dimethylaminoethyl)-4-oxo-1H-quinoline-2-carboxamide hydrochloride exerted protective effects both in the N171-82Q transgenic mouse model of Huntington's disease and the four-vessel occlusion model of cerebral ischemia in rats [310, 311]. At the dose capable of exerting these neuroprotective effects, the KYNA analog did not demonstrate any significant systemic side effects, i.e., it did not alter locomotor activity, working memory performance, and long-lasting, consolidated reference memory in contrast to the observed indirect side-effects following KYN administration [312-314]. These results are supported by 
the findings that instead of decreasing LTP as it might be expected from its potential NMDAR antagonistic properties, it rather facilitated the potentiation of field excitatory postsynaptic potentials [315].

These data together strongly support the therapeutic potential of certain approaches related to the elevation of the levels of KYNA or its analogs in the brain in AD, with carefully keeping in mind the potential cognitive deleterious effects of the inhibition of synaptic NMDA/AMPA receptor-mediated currents during rational drug design.

\section{CONCLUSIONS}

Although more and more details are being revealed regarding the pathomechanism of $\mathrm{AD}$, including mitochondrial dysfunction, glutamate excitotoxicity (Fig. 2), and neuroinflammation (Fig. 3), current therapeutic strategies are restricted only to few pharmaceutical agents. These three aspects of the pathomechanism certainly demonstrate relations to specific alterations in the KYN pathway of TRP metabolism (Fig. 2) [316-318]. Accordingly, the treatment of AD via the modulation of TRP metabolism appears to be a reasonable target of investigation; however, the complexity of the observed alterations and the seemingly narrow therapeutic window necessitate the development of sophisticated pharmaceutical approaches.

\section{ACKNOWLEDGEMENT}

This work was supported by the projects MTA-SZTE Neuroscience Research Group, Hungarian Brain Research Program - Grant No. KTIA_13_NAP-A_III/9, GINOP-2.3.2-152016-00034 ('Molecular Biological Fundamentals of Neurodegenerative and Immune Diseases: Therapeutic Trials with Kynurenines') and EFOP-3.6.1-16-2016-00008 ('Development of intelligent life science technologies, methods, applications and 
development of innovative processes and services based on the knowledge base of Szeged'). Dénes Zádori was supported by the János Bolyai Research Scholarship of the Hungarian Academy of Sciences.

Conflict of interest: none.

\section{REFERENCES}

[1] Robinson M, Lee BY, Hane FT (2017) Recent progress in Alzheimer's disease research, part 2: Genetics and epidemiology. J Alzheimers Dis 57, 317-330.

[2] Hane FT, Lee BY, Leonenko Z (2017) Recent progress in Alzheimer's disease research, part 1: Pathology. J Alzheimers Dis 57, 1-28.

[3] Hane FT, Robinson M, Lee BY, Bai O, Leonenko Z, Albert MS (2017) Recent progress in Alzheimer's disease research, part 3: Diagnosis and treatment. $J$ Alzheimers Dis 57, 645-665.

[4] Tse KH, Herrup K (2017) Re-imagining Alzheimer's disease - the diminishing importance of amyloid and a glimpse of what lies ahead. J Neurochem 143, 432-444.

[5] Vecsei L, Szalardy L, Fulop F, Toldi J (2013) Kynurenines in the CNS: recent advances and new questions. Nat Rev Drug Discov 12, 64-82.

[6] Cabezas-Opazo FA, Vergara-Pulgar K, Perez MJ, Jara C, Osorio-Fuentealba C, Quintanilla RA (2015) Mitochondrial dysfunction contributes to the pathogenesis of Alzheimer's disease. Oxid Med Cell Longev 2015 509654, pp. 1-12.

[7] Adiele RC, Adiele CA (2016) Mitochondrial regulatory pathways in the pathogenesis of Alzheimer's disease. J Alzheimers Dis 53, 1257-1270. 
[8] Cai Q, Tammineni P (2017) Mitochondrial aspects of synaptic dysfunction in Alzheimer's disease. J Alzheimers Dis 57, 1087-1103.

[9] Chan DC (2006) Mitochondrial fusion and fission in mammals. Annu Rev Cell Dev Biol 22, 79-99.

[10] Cagalinec M, Safiulina D, Liiv M, Liiv J, Choubey V, Wareski P, Veksler V, Kaasik A (2013) Principles of the mitochondrial fusion and fission cycle in neurons. J Cell Sci 126, 2187-2197.

[11] Hirai K, Aliev G, Nunomura A, Fujioka H, Russell RL, Atwood CS, Johnson AB, Kress Y, Vinters HV, Tabaton M, Shimohama S, Cash AD, Siedlak SL, Harris PL, Jones PK, Petersen RB, Perry G, Smith MA (2001) Mitochondrial abnormalities in Alzheimer's disease. J Neurosci 21, 3017-3023.

[12] Wang X, Su B, Siedlak SL, Moreira PI, Fujioka H, Wang Y, Casadesus G, Zhu X (2008) Amyloid-beta overproduction causes abnormal mitochondrial dynamics via differential modulation of mitochondrial fission/fusion proteins. Proc Natl Acad Sci U $S$ A 105, 19318-19323.

[13] Wang X, Su B, Lee HG, Li X, Perry G, Smith MA, Zhu X (2009) Impaired balance of mitochondrial fission and fusion in Alzheimer's disease. J Neurosci 29, 9090-9103.

[14] Park J, Choi H, Min JS, Kim B, Lee SR, Yun JW, Choi MS, Chang KT, Lee DS (2015) Loss of mitofusin 2 links beta-amyloid-mediated mitochondrial fragmentation and Cdk5-induced oxidative stress in neuron cells. J Neurochem 132, 687-702.

[15] Calkins MJ, Manczak M, Mao P, Shirendeb U, Reddy PH (2011) Impaired mitochondrial biogenesis, defective axonal transport of mitochondria, abnormal mitochondrial dynamics and synaptic degeneration in a mouse model of Alzheimer's disease. Hum Mol Genet 20, 4515-4529. 
[16] Wang Z, Wang B, Yang L, Guo Q, Aithmitti N, Songyang Z, Zheng H (2009) Presynaptic and postsynaptic interaction of the amyloid precursor protein promotes peripheral and central synaptogenesis. J Neurosci 29, 10788-10801.

[17] Wang X, Perry G, Smith MA, Zhu X (2010) Amyloid-beta-derived diffusible ligands cause impaired axonal transport of mitochondria in neurons. Neurodegener Dis 7, 5659.

[18] Du H, Guo L, Yan S, Sosunov AA, McKhann GM, Yan SS (2010) Early deficits in synaptic mitochondria in an Alzheimer's disease mouse model. Proc Natl Acad Sci U $S$ A 107, 18670-18675.

[19] Manczak M, Anekonda TS, Henson E, Park BS, Quinn J, Reddy PH (2006) Mitochondria are a direct site of A beta accumulation in Alzheimer's disease neurons: implications for free radical generation and oxidative damage in disease progression. Hum Mol Genet 15, 1437-1449.

[20] Devi L, Prabhu BM, Galati DF, Avadhani NG, Anandatheerthavarada HK (2006) Accumulation of amyloid precursor protein in the mitochondrial import channels of human Alzheimer's disease brain is associated with mitochondrial dysfunction. $J$ Neurosci 26, 9057-9068.

[21] Hansson Petersen CA, Alikhani N, Behbahani H, Wiehager B, Pavlov PF, Alafuzoff I, Leinonen V, Ito A, Winblad B, Glaser E, Ankarcrona M (2008) The amyloid betapeptide is imported into mitochondria via the TOM import machinery and localized to mitochondrial cristae. Proc Natl Acad Sci U S A 105, 13145-13150.

[22] Dragicevic N, Mamcarz M, Zhu Y, Buzzeo R, Tan J, Arendash GW, Bradshaw PC (2010) Mitochondrial amyloid-beta levels are associated with the extent of mitochondrial dysfunction in different brain regions and the degree of cognitive impairment in Alzheimer's transgenic mice. J Alzheimers Dis 20 Suppl 2, S535-550. 
[23] Manczak M, Calkins MJ, Reddy PH (2011) Impaired mitochondrial dynamics and abnormal interaction of amyloid beta with mitochondrial protein Drp1 in neurons from patients with Alzheimer's disease: implications for neuronal damage. Hum Mol Genet 20, 2495-2509.

[24] DuBoff B, Gotz J, Feany MB (2012) Tau promotes neurodegeneration via DRP1 mislocalization in vivo. Neuron 75, 618-632.

[25] Schulz KL, Eckert A, Rhein V, Mai S, Haase W, Reichert AS, Jendrach M, Muller WE, Leuner K (2012) A new link to mitochondrial impairment in tauopathies. Mol Neurobiol 46, 205-216.

[26] Manczak M, Reddy PH (2012) Abnormal interaction between the mitochondrial fission protein Drp1 and hyperphosphorylated tau in Alzheimer's disease neurons: implications for mitochondrial dysfunction and neuronal damage. Hum Mol Genet 21, 2538-2547.

[27] Rhein V, Song X, Wiesner A, Ittner LM, Baysang G, Meier F, Ozmen L, Bluethmann H, Drose S, Brandt U, Savaskan E, Czech C, Gotz J, Eckert A (2009) Amyloid-beta and tau synergistically impair the oxidative phosphorylation system in triple transgenic Alzheimer's disease mice. Proc Natl Acad Sci U S A 106, 20057-20062.

[28] Yao J, Du H, Yan S, Fang F, Wang C, Lue LF, Guo L, Chen D, Stern DM, Gunn Moore FJ, Xi Chen J, Arancio O, Yan SS (2011) Inhibition of amyloid-beta (Abeta) peptide-binding alcohol dehydrogenase-Abeta interaction reduces Abeta accumulation and improves mitochondrial function in a mouse model of Alzheimer's disease. $J$ Neurosci 31, 2313-2320.

[29] Parker WD, Jr., Filley CM, Parks JK (1990) Cytochrome oxidase deficiency in Alzheimer's disease. Neurology 40, 1302-1303. 
[30] Mutisya EM, Bowling AC, Beal MF (1994) Cortical cytochrome oxidase activity is reduced in Alzheimer's disease. J Neurochem 63, 2179-2184.

[31] Schagger H, Ohm TG (1995) Human diseases with defects in oxidative phosphorylation. 2. F1F0 ATP-synthase defects in Alzheimer disease revealed by blue native polyacrylamide gel electrophoresis. Eur J Biochem 227, 916-921.

[32] Maurer I, Zierz S, Moller HJ (2000) A selective defect of cytochrome c oxidase is present in brain of Alzheimer disease patients. Neurobiol Aging 21, 455-462.

[33] Manczak M, Park BS, Jung Y, Reddy PH (2004) Differential expression of oxidative phosphorylation genes in patients with Alzheimer's disease: implications for early mitochondrial dysfunction and oxidative damage. Neuromolecular Med 5, 147-162.

[34] Sorbi S, Bird ED, Blass JP (1983) Decreased pyruvate dehydrogenase complex activity in Huntington and Alzheimer brain. Ann Neurol 13, 72-78.

[35] Sheu KF, Kim YT, Blass JP, Weksler ME (1985) An immunochemical study of the pyruvate dehydrogenase deficit in Alzheimer's disease brain. Ann Neurol 17, 444-449.

[36] Mastrogiacomo F, Bergeron C, Kish SJ (1993) Brain alpha-ketoglutarate dehydrogenase complex activity in Alzheimer's disease. J Neurochem 61, 2007-2014.

[37] Richards JG, Higgins GA, Ouagazzal AM, Ozmen L, Kew JN, Bohrmann B, Malherbe P, Brockhaus M, Loetscher H, Czech C, Huber G, Bluethmann H, Jacobsen H, Kemp JA (2003) PS2APP transgenic mice, coexpressing hPS2mut and hAPPswe, show age-related cognitive deficits associated with discrete brain amyloid deposition and inflammation. J Neurosci $\mathbf{2 3}, 8989-9003$.

[38] Keil U, Bonert A, Marques CA, Scherping I, Weyermann J, Strosznajder JB, MullerSpahn F, Haass C, Czech C, Pradier L, Muller WE, Eckert A (2004) Amyloid betainduced changes in nitric oxide production and mitochondrial activity lead to apoptosis. J Biol Chem 279, 50310-50320. 
[39] Crouch PJ, Blake R, Duce JA, Ciccotosto GD, Li QX, Barnham KJ, Curtain CC, Cherny RA, Cappai R, Dyrks T, Masters CL, Trounce IA (2005) Copper-dependent inhibition of human cytochrome c oxidase by a dimeric conformer of amyloid-beta142. J Neurosci 25, 672-679.

[40] Gillardon F, Rist W, Kussmaul L, Vogel J, Berg M, Danzer K, Kraut N, Hengerer B (2007) Proteomic and functional alterations in brain mitochondria from $\operatorname{Tg} 2576$ mice occur before amyloid plaque deposition. Proteomics 7, 605-616.

[41] Eckert A, Hauptmann S, Scherping I, Meinhardt J, Rhein V, Drose S, Brandt U, Fandrich M, Muller WE, Gotz J (2008) Oligomeric and fibrillar species of betaamyloid (A beta 42) both impair mitochondrial function in P301L tau transgenic mice. J Mol Med (Berl) 86, 1255-1267.

[42] Hauptmann S, Scherping I, Drose S, Brandt U, Schulz KL, Jendrach M, Leuner K, Eckert A, Muller WE (2009) Mitochondrial dysfunction: an early event in Alzheimer pathology accumulates with age in AD transgenic mice. Neurobiol Aging 30, 15741586.

[43] Yao J, Irwin RW, Zhao L, Nilsen J, Hamilton RT, Brinton RD (2009) Mitochondrial bioenergetic deficit precedes Alzheimer's pathology in female mouse model of Alzheimer's disease. Proc Natl Acad Sci U S A 106, 14670-14675.

[44] Hyun DH, Mughal MR, Yang H, Lee JH, Ko EJ, Hunt ND, de Cabo R, Mattson MP (2010) The plasma membrane redox system is impaired by amyloid beta-peptide and in the hippocampus and cerebral cortex of 3xTgAD mice. Exp Neurol 225, 423-429.

[45] Leuner K, Schutt T, Kurz C, Eckert SH, Schiller C, Occhipinti A, Mai S, Jendrach M, Eckert GP, Kruse SE, Palmiter RD, Brandt U, Drose S, Wittig I, Willem M, Haass C, Reichert AS, Muller WE (2012) Mitochondrion-derived reactive oxygen species lead to enhanced amyloid beta formation. Antioxid Redox Signal 16, 1421-1433. 
[46] Stockburger C, Gold VA, Pallas T, Kolesova N, Miano D, Leuner K, Muller WE (2014) A cell model for the initial phase of sporadic Alzheimer's disease. J Alzheimers Dis 42, 395-411.

[47] Grimm A, Biliouris EE, Lang UE, Gotz J, Mensah-Nyagan AG, Eckert A (2016) Sex hormone-related neurosteroids differentially rescue bioenergetic deficits induced by amyloid-beta or hyperphosphorylated tau protein. Cell Mol Life Sci 73, 201-215.

[48] Mecocci P, MacGarvey U, Beal MF (1994) Oxidative damage to mitochondrial DNA is increased in Alzheimer's disease. Ann Neurol 36, 747-751.

[49] Lin MT, Simon DK, Ahn CH, Kim LM, Beal MF (2002) High aggregate burden of somatic mtDNA point mutations in aging and Alzheimer's disease brain. Hum Mol Genet 11, 133-145.

[50] Wei W, Keogh MJ, Wilson I, Coxhead J, Ryan S, Rollinson S, Griffin H, KurzawaAkanbi M, Santibanez-Koref M, Talbot K, Turner MR, McKenzie CA, Troakes C, Attems J, Smith C, Al Sarraj S, Morris CM, Ansorge O, Pickering-Brown S, Ironside JW, Chinnery PF (2017) Mitochondrial DNA point mutations and relative copy number in 1363 disease and control human brains. Acta Neuropathol Commun 5 13, pp. 1-8.

[51] Wei W, Keogh MJ, Wilson I, Coxhead J, Ryan S, Rollinson S, Griffin H, KurzawaAkanbi M, Santibanez-Koref M, Talbot K, Turner MR, McKenzie CA, Troakes C, Attems J, Smith C, Al Sarraj S, Morris CM, Ansorge O, Pickering-Brown S, Ironside JW, Chinnery PF (2017) Erratum to: Mitochondrial DNA point mutations and relative copy number in 1363 disease and control human brains. Acta Neuropathol Commun 5 17, p. 1 .

[52] Yamaguchi H, Yamazaki T, Ishiguro K, Shoji M, Nakazato Y, Hirai S (1992) Ultrastructural localization of Alzheimer amyloid beta/A4 protein precursor in the 
cytoplasm of neurons and senile plaque-associated astrocytes. Acta Neuropathol $\mathbf{8 5}$, $15-22$.

[53] Parks JK, Smith TS, Trimmer PA, Bennett JP, Jr., Parker WD, Jr. (2001) Neurotoxic Abeta peptides increase oxidative stress in vivo through NMDA-receptor and nitricoxide-synthase mechanisms, and inhibit complex IV activity and induce a mitochondrial permeability transition in vitro. J Neurochem 76, 1050-1056.

[54] Casley CS, Canevari L, Land JM, Clark JB, Sharpe MA (2002) Beta-amyloid inhibits integrated mitochondrial respiration and key enzyme activities. J Neurochem $\mathbf{8 0}$, 91100.

[55] Casley CS, Land JM, Sharpe MA, Clark JB, Duchen MR, Canevari L (2002) Betaamyloid fragment 25-35 causes mitochondrial dysfunction in primary cortical neurons. Neurobiol Dis 10, 258-267.

[56] Aleardi AM, Benard G, Augereau O, Malgat M, Talbot JC, Mazat JP, Letellier T, Dachary-Prigent J, Solaini GC, Rossignol R (2005) Gradual alteration of mitochondrial structure and function by beta-amyloids: importance of membrane viscosity changes, energy deprivation, reactive oxygen species production, and cytochrome c release. J Bioenerg Biomembr 37, 207-225.

[57] Lustbader JW, Cirilli M, Lin C, Xu HW, Takuma K, Wang N, Caspersen C, Chen X, Pollak S, Chaney M, Trinchese F, Liu S, Gunn-Moore F, Lue LF, Walker DG, Kuppusamy P, Zewier ZL, Arancio O, Stern D, Yan SS, Wu H (2004) ABAD directly links Abeta to mitochondrial toxicity in Alzheimer's disease. Science 304, 448-452.

[58] Du H, Guo L, Fang F, Chen D, Sosunov AA, McKhann GM, Yan Y, Wang C, Zhang H, Molkentin JD, Gunn-Moore FJ, Vonsattel JP, Arancio O, Chen JX, Yan SD (2008) Cyclophilin D deficiency attenuates mitochondrial and neuronal perturbation and ameliorates learning and memory in Alzheimer's disease. Nat Med 14, 1097-1105. 
[59] Manczak M, Reddy PH (2012) Abnormal interaction of VDAC1 with amyloid beta and phosphorylated tau causes mitochondrial dysfunction in Alzheimer's disease. Hum Mol Genet 21, 5131-5146.

[60] Mattson MP, Partin J, Begley JG (1998) Amyloid beta-peptide induces apoptosisrelated events in synapses and dendrites. Brain Res 807, 167-176.

[61] Mungarro-Menchaca X, Ferrera P, Moran J, Arias C (2002) beta-Amyloid peptide induces ultrastructural changes in synaptosomes and potentiates mitochondrial dysfunction in the presence of ryanodine. J Neurosci Res 68, 89-96.

[62] D'Amelio M, Cavallucci V, Middei S, Marchetti C, Pacioni S, Ferri A, Diamantini A, De Zio D, Carrara P, Battistini L, Moreno S, Bacci A, Ammassari-Teule M, Marie H, Cecconi F (2011) Caspase-3 triggers early synaptic dysfunction in a mouse model of Alzheimer's disease. Nat Neurosci 14, 69-76.

[63] Bartley MG, Marquardt K, Kirchhof D, Wilkins HM, Patterson D, Linseman DA (2012) Overexpression of amyloid-beta protein precursor induces mitochondrial oxidative stress and activates the intrinsic apoptotic cascade. J Alzheimers Dis $\mathbf{2 8}$, 855-868.

[64] Gabuzda D, Busciglio J, Chen LB, Matsudaira P, Yankner BA (1994) Inhibition of energy metabolism alters the processing of amyloid precursor protein and induces a potentially amyloidogenic derivative. J Biol Chem 269, 13623-13628.

[65] Tamagno E, Parola M, Bardini P, Piccini A, Borghi R, Guglielmotto M, Santoro G, Davit A, Danni O, Smith MA, Perry G, Tabaton M (2005) Beta-site APP cleaving enzyme up-regulation induced by 4-hydroxynonenal is mediated by stress-activated protein kinases pathways. J Neurochem 92, 628-636.

[66] Tamagno E, Guglielmotto M, Aragno M, Borghi R, Autelli R, Giliberto L, Muraca G, Danni O, Zhu X, Smith MA, Perry G, Jo DG, Mattson MP, Tabaton M (2008) 
Oxidative stress activates a positive feedback between the gamma- and beta-secretase cleavages of the beta-amyloid precursor protein. J Neurochem 104, 683-695.

[67] Guglielmotto M, Aragno M, Autelli R, Giliberto L, Novo E, Colombatto S, Danni O, Parola M, Smith MA, Perry G, Tamagno E, Tabaton M (2009) The up-regulation of BACE1 mediated by hypoxia and ischemic injury: role of oxidative stress and HIF1 alpha. J Neurochem 108, 1045-1056.

[68] Dumont M, Stack C, Elipenahli C, Jainuddin S, Gerges M, Starkova NN, Yang L, Starkov AA, Beal F (2011) Behavioral deficit, oxidative stress, and mitochondrial dysfunction precede tau pathology in P301S transgenic mice. FASEB J 25, 4063-4072.

[69] David DC, Hauptmann S, Scherping I, Schuessel K, Keil U, Rizzu P, Ravid R, Drose S, Brandt U, Muller WE, Eckert A, Gotz J (2005) Proteomic and functional analyses reveal a mitochondrial dysfunction in P301L tau transgenic mice. J Biol Chem 280, $23802-23814$.

[70] Bu G (2009) Apolipoprotein E and its receptors in Alzheimer's disease: pathways, pathogenesis and therapy. Nat Rev Neurosci 10, 333-344.

[71] Holtzman DM, Herz J, Bu G (2012) Apolipoprotein E and apolipoprotein E receptors: normal biology and roles in Alzheimer disease. Cold Spring Harb Perspect Med $\mathbf{2}$ a006312, pp. 1-23.

[72] Liu CC, Kanekiyo T, Xu H, Bu G (2013) Apolipoprotein E and Alzheimer disease: risk, mechanisms and therapy. Nat Rev Neurol 9, 106-118.

[73] Grimm A, Friedland K, Eckert A (2016) Mitochondrial dysfunction: the missing link between aging and sporadic Alzheimer's disease. Biogerontology 17, 281-296.

[74] Gibson GE, Haroutunian V, Zhang H, Park LC, Shi Q, Lesser M, Mohs RC, Sheu RK, Blass JP (2000) Mitochondrial damage in Alzheimer's disease varies with apolipoprotein E genotype. Ann Neurol 48, 297-303. 
[75] Chen HK, Ji ZS, Dodson SE, Miranda RD, Rosenblum CI, Reynolds IJ, Freedman SB, Weisgraber KH, Huang Y, Mahley RW (2011) Apolipoprotein E4 domain interaction mediates detrimental effects on mitochondria and is a potential therapeutic target for Alzheimer disease. J Biol Chem 286, 5215-5221.

[76] Nakamura T, Watanabe A, Fujino T, Hosono T, Michikawa M (2009) Apolipoprotein E4 (1-272) fragment is associated with mitochondrial proteins and affects mitochondrial function in neuronal cells. Mol Neurodegener 4 35, pp. 1-11.

[77] Hollenbeck PJ, Saxton WM (2005) The axonal transport of mitochondria. J Cell Sci 118, 5411-5419.

[78] Sheng ZH (2014) Mitochondrial trafficking and anchoring in neurons: New insight and implications. J Cell Biol 204, 1087-1098.

[79] Dai J, Buijs RM, Kamphorst W, Swaab DF (2002) Impaired axonal transport of cortical neurons in Alzheimer's disease is associated with neuropathological changes. Brain Res 948, 138-144.

[80] Pigino G, Morfini G, Pelsman A, Mattson MP, Brady ST, Busciglio J (2003) Alzheimer's presenilin 1 mutations impair kinesin-based axonal transport. $J$ Neurosci 23, 4499-4508.

[81] Stokin GB, Lillo C, Falzone TL, Brusch RG, Rockenstein E, Mount SL, Raman R, Davies P, Masliah E, Williams DS, Goldstein LS (2005) Axonopathy and transport deficits early in the pathogenesis of Alzheimer's disease. Science 307, 1282-1288.

[82] Rui Y, Tiwari P, Xie Z, Zheng JQ (2006) Acute impairment of mitochondrial trafficking by beta-amyloid peptides in hippocampal neurons. J Neurosci 26, 1048010487.

[83] Lazarov O, Morfini GA, Pigino G, Gadadhar A, Chen X, Robinson J, Ho H, Brady ST, Sisodia SS (2007) Impairments in fast axonal transport and motor neuron deficits 
in transgenic mice expressing familial Alzheimer's disease-linked mutant presenilin 1.

J Neurosci 27, 7011-7020.

[84] Vossel KA, Zhang K, Brodbeck J, Daub AC, Sharma P, Finkbeiner S, Cui B, Mucke L (2010) Tau reduction prevents Abeta-induced defects in axonal transport. Science 330, 198.

[85] Calkins MJ, Reddy PH (2011) Amyloid beta impairs mitochondrial anterograde transport and degenerates synapses in Alzheimer's disease neurons. Biochim Biophys Acta 1812, 507-513.

[86] Reddy PH (2011) Abnormal tau, mitochondrial dysfunction, impaired axonal transport of mitochondria, and synaptic deprivation in Alzheimer's disease. Brain Res 1415, 136-148.

[87] Reddy PH, Tripathi R, Troung Q, Tirumala K, Reddy TP, Anekonda V, Shirendeb UP, Calkins MJ, Reddy AP, Mao P, Manczak M (2012) Abnormal mitochondrial dynamics and synaptic degeneration as early events in Alzheimer's disease: implications to mitochondria-targeted antioxidant therapeutics. Biochim Biophys Acta 1822, 639-649.

[88] Deng Y, Xiong Z, Chen P, Wei J, Chen S, Yan Z (2014) Beta-amyloid impairs the regulation of N-methyl-D-aspartate receptors by glycogen synthase kinase 3 . Neurobiol Aging 35, 449-459.

[89] Vossel KA, Xu JC, Fomenko V, Miyamoto T, Suberbielle E, Knox JA, Ho K, Kim DH, Yu GQ, Mucke L (2015) Tau reduction prevents Abeta-induced axonal transport deficits by blocking activation of GSK3beta. J Cell Biol 209, 419-433.

[90] Qin W, Haroutunian V, Katsel P, Cardozo CP, Ho L, Buxbaum JD, Pasinetti GM (2009) PGC-1alpha expression decreases in the Alzheimer disease brain as a function of dementia. Arch Neurol 66, 352-361. 
[91] Sheng B, Wang X, Su B, Lee HG, Casadesus G, Perry G, Zhu X (2012) Impaired mitochondrial biogenesis contributes to mitochondrial dysfunction in Alzheimer's disease. J Neurochem 120, 419-429.

[92] Abramov E, Dolev I, Fogel H, Ciccotosto GD, Ruff E, Slutsky I (2009) Amyloid-beta as a positive endogenous regulator of release probability at hippocampal synapses. Nat Neurosci 12, 1567-1576.

[93] Puzzo D, Privitera L, Fa M, Staniszewski A, Hashimoto G, Aziz F, Sakurai M, Ribe EM, Troy CM, Mercken M, Jung SS, Palmeri A, Arancio O (2011) Endogenous amyloid-beta is necessary for hippocampal synaptic plasticity and memory. Ann Neurol 69, 819-830.

[94] Parameshwaran K, Dhanasekaran M, Suppiramaniam V (2008) Amyloid beta peptides and glutamatergic synaptic dysregulation. Exp Neurol 210, 7-13.

[95] Tovar KR, Westbrook GL (1999) The incorporation of NMDA receptors with a distinct subunit composition at nascent hippocampal synapses in vitro. J Neurosci 19, 4180-4188.

[96] Hardingham GE, Fukunaga Y, Bading H (2002) Extrasynaptic NMDARs oppose synaptic NMDARs by triggering CREB shut-off and cell death pathways. Nat Neurosci 5, 405-414.

[97] Ivanov A, Pellegrino C, Rama S, Dumalska I, Salyha Y, Ben-Ari Y, Medina I (2006) Opposing role of synaptic and extrasynaptic NMDA receptors in regulation of the extracellular signal-regulated kinases (ERK) activity in cultured rat hippocampal neurons. J Physiol 572, 789-798.

[98] Goebel-Goody SM, Davies KD, Alvestad Linger RM, Freund RK, Browning MD (2009) Phospho-regulation of synaptic and extrasynaptic N-methyl-d-aspartate receptors in adult hippocampal slices. Neuroscience 158, 1446-1459. 
[99] Huang Y, Shen W, Su J, Cheng B, Li D, Liu G, Zhou WX, Zhang YX (2017)

Modulating the balance of synaptic and extrasynaptic NMDA receptors shows positive effects against amyloid-beta-induced neurotoxicity. J Alzheimers Dis $\mathbf{5 7}, 885$ 897.

[100] Zhou Q, Sheng M (2013) NMDA receptors in nervous system diseases. Neuropharmacology 74, 69-75.

[101] Kim JH, Anwyl R, Suh YH, Djamgoz MB, Rowan MJ (2001) Use-dependent effects of amyloidogenic fragments of (beta)-amyloid precursor protein on synaptic plasticity in rat hippocampus in vivo. J Neurosci 21, 1327-1333.

[102] Baudry M, Lynch G (2001) Remembrance of arguments past: how well is the glutamate receptor hypothesis of LTP holding up after 20 years? Neurobiol Learn Mem 76, 284-297.

[103] Wang HW, Pasternak JF, Kuo H, Ristic H, Lambert MP, Chromy B, Viola KL, Klein WL, Stine WB, Krafft GA, Trommer BL (2002) Soluble oligomers of beta amyloid (1-42) inhibit long-term potentiation but not long-term depression in rat dentate gyrus. Brain Res 924, 133-140.

[104] Escobar ML, Derrick B (2007) Long-Term Potentiation and Depression as Putative Mechanisms for Memory Formation In Neural Plasticity and Memory: From Genes to Brain Imaging., Bermúdez-Rattoni F, ed. CRC Press, Boca Raton (FL), pp. 15-45.

[105] Snyder EM, Nong Y, Almeida CG, Paul S, Moran T, Choi EY, Nairn AC, Salter MW, Lombroso PJ, Gouras GK, Greengard P (2005) Regulation of NMDA receptor trafficking by amyloid-beta. Nat Neurosci $\mathbf{8}, 1051-1058$.

[106] Hsieh H, Boehm J, Sato C, Iwatsubo T, Tomita T, Sisodia S, Malinow R (2006) AMPAR removal underlies Abeta-induced synaptic depression and dendritic spine loss. Neuron 52, 831-843. 
[107] Ferreira IL, Bajouco LM, Mota SI, Auberson YP, Oliveira CR, Rego AC (2012) Amyloid beta peptide 1-42 disturbs intracellular calcium homeostasis through activation of GluN2B-containing N-methyl-d-aspartate receptors in cortical cultures. Cell Calcium 51, 95-106.

[108] Sattler R, Xiong Z, Lu WY, Hafner M, MacDonald JF, Tymianski M (1999) Specific coupling of NMDA receptor activation to nitric oxide neurotoxicity by PSD-95 protein. Science 284, 1845-1848.

[109] Liu Y, Wong TP, Aarts M, Rooyakkers A, Liu L, Lai TW, Wu DC, Lu J, Tymianski M, Craig AM, Wang YT (2007) NMDA receptor subunits have differential roles in mediating excitotoxic neuronal death both in vitro and in vivo. J Neurosci 27, 28462857.

[110] Lacor PN, Buniel MC, Furlow PW, Clemente AS, Velasco PT, Wood M, Viola KL, Klein WL (2007) Abeta oligomer-induced aberrations in synapse composition, shape, and density provide a molecular basis for loss of connectivity in Alzheimer's disease. $J$ Neurosci 27, 796-807.

[111] Bordji K, Becerril-Ortega J, Nicole O, Buisson A (2010) Activation of extrasynaptic, but not synaptic, NMDA receptors modifies amyloid precursor protein expression pattern and increases amyloid-ss production. J Neurosci 30, 15927-15942.

[112] Danysz W, Parsons CG (2012) Alzheimer's disease, beta-amyloid, glutamate, NMDA receptors and memantine--searching for the connections. Br J Pharmacol 167, 324352.

[113] Amadoro G, Ciotti MT, Costanzi M, Cestari V, Calissano P, Canu N (2006) NMDA receptor mediates tau-induced neurotoxicity by calpain and ERK/MAPK activation. Proc Natl Acad Sci U S A 103, 2892-2897. 
[114] Roberson ED, Halabisky B, Yoo JW, Yao J, Chin J, Yan F, Wu T, Hamto P, Devidze N, Yu GQ, Palop JJ, Noebels JL, Mucke L (2011) Amyloid-beta/Fyn-induced synaptic, network, and cognitive impairments depend on tau levels in multiple mouse models of Alzheimer's disease. J Neurosci 31, 700-711.

[115] Ittner LM, Gotz J (2011) Amyloid-beta and tau - a toxic pas de deux in Alzheimer's disease. Nat Rev Neurosci 12, 65-72.

[116] Mattson MP, Cheng B, Davis D, Bryant K, Lieberburg I, Rydel RE (1992) Betaamyloid peptides destabilize calcium homeostasis and render human cortical neurons vulnerable to excitotoxicity. J Neurosci 12, 376-389.

[117] Parpura-Gill A, Beitz D, Uemura E (1997) The inhibitory effects of beta-amyloid on glutamate and glucose uptakes by cultured astrocytes. Brain Res 754, 65-71.

[118] Fernandez-Tome P, Brera B, Arevalo MA, de Ceballos ML (2004) Beta-amyloid25-35 inhibits glutamate uptake in cultured neurons and astrocytes: modulation of uptake as a survival mechanism. Neurobiol Dis 15, 580-589.

[119] Matos M, Augusto E, Oliveira CR, Agostinho P (2008) Amyloid-beta peptide decreases glutamate uptake in cultured astrocytes: involvement of oxidative stress and mitogen-activated protein kinase cascades. Neuroscience 156, 898-910.

[120] Scimemi A, Meabon JS, Woltjer RL, Sullivan JM, Diamond JS, Cook DG (2013) Amyloid-beta1-42 slows clearance of synaptically released glutamate by mislocalizing astrocytic GLT-1. J Neurosci 33, 5312-5318.

[121] Talantova M, Sanz-Blasco S, Zhang X, Xia P, Akhtar MW, Okamoto S, Dziewczapolski G, Nakamura T, Cao G, Pratt AE, Kang YJ, Tu S, Molokanova E, McKercher SR, Hires SA, Sason H, Stouffer DG, Buczynski MW, Solomon JP, Michael S, Powers ET, Kelly JW, Roberts A, Tong G, Fang-Newmeyer T, Parker J, Holland EA, Zhang D, Nakanishi N, Chen HS, Wolosker H, Wang Y, Parsons LH, 
Ambasudhan R, Masliah E, Heinemann SF, Pina-Crespo JC, Lipton SA (2013) Abeta induces astrocytic glutamate release, extrasynaptic NMDA receptor activation, and synaptic loss. Proc Natl Acad Sci U S A 110, E2518-2527.

[122] Schallier A, Smolders I, Van Dam D, Loyens E, De Deyn PP, Michotte A, Michotte Y, Massie A (2011) Region- and age-specific changes in glutamate transport in the AbetaPP23 mouse model for Alzheimer's disease. J Alzheimers Dis 24, 287-300.

[123] Zumkehr J, Rodriguez-Ortiz CJ, Cheng D, Kieu Z, Wai T, Hawkins C, Kilian J, Lim SL, Medeiros R, Kitazawa M (2015) Ceftriaxone ameliorates tau pathology and cognitive decline via restoration of glial glutamate transporter in a mouse model of Alzheimer's disease. Neurobiol Aging 36, 2260-2271.

[124] Li S, Mallory M, Alford M, Tanaka S, Masliah E (1997) Glutamate transporter alterations in Alzheimer disease are possibly associated with abnormal APP expression. J Neuropathol Exp Neurol 56, 901-911.

[125] Beckstrom H, Julsrud L, Haugeto O, Dewar D, Graham DI, Lehre KP, StormMathisen J, Danbolt NC (1999) Interindividual differences in the levels of the glutamate transporters GLAST and GLT, but no clear correlation with Alzheimer's disease. J Neurosci Res 55, 218-229.

[126] Scott HA, Gebhardt FM, Mitrovic AD, Vandenberg RJ, Dodd PR (2011) Glutamate transporter variants reduce glutamate uptake in Alzheimer's disease. Neurobiol Aging 32 553, pp. 1-11.

[127] Lewerenz J, Maher P (2015) Chronic glutamate toxicity in neurodegenerative diseases-What is the evidence? Front Neurosci 9 469, pp. 1-20.

[128] Qin S, Colin C, Hinners I, Gervais A, Cheret C, Mallat M (2006) System Xc- and apolipoprotein E expressed by microglia have opposite effects on the neurotoxicity of amyloid-beta peptide 1-40. J Neurosci 26, 3345-3356. 
[129] Novelli A, Reilly JA, Lysko PG, Henneberry RC (1988) Glutamate becomes neurotoxic via the $\mathrm{N}$-methyl-D-aspartate receptor when intracellular energy levels are reduced. Brain Res 451, 205-212.

[130] Heneka MT, Carson MJ, El Khoury J, Landreth GE, Brosseron F, Feinstein DL, Jacobs AH, Wyss-Coray T, Vitorica J, Ransohoff RM, Herrup K, Frautschy SA, Finsen B, Brown GC, Verkhratsky A, Yamanaka K, Koistinaho J, Latz E, Halle A, Petzold GC, Town T, Morgan D, Shinohara ML, Perry VH, Holmes C, Bazan NG, Brooks DJ, Hunot S, Joseph B, Deigendesch N, Garaschuk O, Boddeke E, Dinarello CA, Breitner JC, Cole GM, Golenbock DT, Kummer MP (2015) Neuroinflammation in Alzheimer's disease. Lancet Neurol 14, 388-405.

[131] Heppner FL, Ransohoff RM, Becher B (2015) Immune attack: the role of inflammation in Alzheimer disease. Nat Rev Neurosci 16, 358-372.

[132] Raj T, Rothamel K, Mostafavi S, Ye C, Lee MN, Replogle JM, Feng T, Lee M, Asinovski N, Frohlich I, Imboywa S, Von Korff A, Okada Y, Patsopoulos NA, Davis S, McCabe C, Paik HI, Srivastava GP, Raychaudhuri S, Hafler DA, Koller D, Regev A, Hacohen N, Mathis D, Benoist C, Stranger BE, De Jager PL (2014) Polarization of the effects of autoimmune and neurodegenerative risk alleles in leukocytes. Science 344, 519-523.

[133] Kettenmann H, Hanisch UK, Noda M, Verkhratsky A (2011) Physiology of microglia. Physiol Rev 91, 461-553.

[134] Ji K, Akgul G, Wollmuth LP, Tsirka SE (2013) Microglia actively regulate the number of functional synapses. PLoS One $\mathbf{8}$ e56293, pp. 1-12.

[135] Parkhurst CN, Yang G, Ninan I, Savas JN, Yates JR, 3rd, Lafaille JJ, Hempstead BL, Littman DR, Gan WB (2013) Microglia promote learning-dependent synapse formation through brain-derived neurotrophic factor. Cell 155, 1596-1609. 
[136] Perlmutter LS, Scott SA, Barron E, Chui HC (1992) MHC class II-positive microglia in human brain: association with Alzheimer lesions. J Neurosci Res 33, 549-558.

[137] Yasuno F, Kosaka J, Ota M, Higuchi M, Ito H, Fujimura Y, Nozaki S, Takahashi S, Mizukami K, Asada T, Suhara T (2012) Increased binding of peripheral benzodiazepine receptor in mild cognitive impairment-dementia converters measured by positron emission tomography with [(1)(1)C]DAA1106. Psychiatry Res 203, 6774.

[138] Schuitemaker A, Kropholler MA, Boellaard R, van der Flier WM, Kloet RW, van der Doef TF, Knol DL, Windhorst AD, Luurtsema G, Barkhof F, Jonker C, Lammertsma AA, Scheltens P, van Berckel BN (2013) Microglial activation in Alzheimer's disease: an (R)-[(1)(1)C]PK11195 positron emission tomography study. Neurobiol Aging 34, 128-136.

[139] Akama KT, Van Eldik LJ (2000) Beta-amyloid stimulation of inducible nitric-oxide synthase in astrocytes is interleukin-1beta- and tumor necrosis factor-alpha (TNFalpha)-dependent, and involves a TNFalpha receptor-associated factor- and NFkappaB-inducing kinase-dependent signaling mechanism. J Biol Chem 275, 79187924.

[140] Lue LF, Rydel R, Brigham EF, Yang LB, Hampel H, Murphy GM, Jr., Brachova L, Yan SD, Walker DG, Shen Y, Rogers J (2001) Inflammatory repertoire of Alzheimer's disease and nondemented elderly microglia in vitro. Glia 35, 72-79.

[141] Walker DG, Link J, Lue LF, Dalsing-Hernandez JE, Boyes BE (2006) Gene expression changes by amyloid beta peptide-stimulated human postmortem brain microglia identify activation of multiple inflammatory processes. J Leukoc Biol 79, 596-610. 
[142] Lee CY, Landreth GE (2010) The role of microglia in amyloid clearance from the AD brain. J Neural Transm (Vienna) 117, 949-960.

[143] Prokop S, Miller KR, Heppner FL (2013) Microglia actions in Alzheimer's disease. Acta Neuropathol 126, 461-477.

[144] Hickman SE, Allison EK, El Khoury J (2008) Microglial dysfunction and defective beta-amyloid clearance pathways in aging Alzheimer's disease mice. $J$ Neurosci $\mathbf{2 8}$, 8354-8360.

[145] Lambert JC, Heath S, Even G, Campion D, Sleegers K, Hiltunen M, Combarros O, Zelenika D, Bullido MJ, Tavernier B, Letenneur L, Bettens K, Berr C, Pasquier F, Fievet N, Barberger-Gateau P, Engelborghs S, De Deyn P, Mateo I, Franck A, Helisalmi S, Porcellini E, Hanon O, de Pancorbo MM, Lendon C, Dufouil C, Jaillard C, Leveillard T, Alvarez V, Bosco P, Mancuso M, Panza F, Nacmias B, Bossu P, Piccardi P, Annoni G, Seripa D, Galimberti D, Hannequin D, Licastro F, Soininen H, Ritchie K, Blanche H, Dartigues JF, Tzourio C, Gut I, Van Broeckhoven C, Alperovitch A, Lathrop M, Amouyel P (2009) Genome-wide association study identifies variants at CLU and CR1 associated with Alzheimer's disease. Nat Genet 41, 1094-1099.

[146] Hollingworth P, Harold D, Sims R, Gerrish A, Lambert JC, Carrasquillo MM, Abraham R, Hamshere ML, Pahwa JS, Moskvina V, Dowzell K, Jones N, Stretton A, Thomas C, Richards A, Ivanov D, Widdowson C, Chapman J, Lovestone S, Powell J, Proitsi P, Lupton MK, Brayne C, Rubinsztein DC, Gill M, Lawlor B, Lynch A, Brown KS, Passmore PA, Craig D, McGuinness B, Todd S, Holmes C, Mann D, Smith AD, Beaumont H, Warden D, Wilcock G, Love S, Kehoe PG, Hooper NM, Vardy ER, Hardy J, Mead S, Fox NC, Rossor M, Collinge J, Maier W, Jessen F, Ruther E, Schurmann B, Heun R, Kolsch H, van den Bussche H, Heuser I, Kornhuber J, 
Wiltfang J, Dichgans M, Frolich L, Hampel H, Gallacher J, Hull M, Rujescu D, Giegling I, Goate AM, Kauwe JS, Cruchaga C, Nowotny P, Morris JC, Mayo K, Sleegers K, Bettens K, Engelborghs S, De Deyn PP, Van Broeckhoven C, Livingston G, Bass NJ, Gurling H, McQuillin A, Gwilliam R, Deloukas P, Al-Chalabi A, Shaw CE, Tsolaki M, Singleton AB, Guerreiro R, Muhleisen TW, Nothen MM, Moebus S, Jockel KH, Klopp N, Wichmann HE, Pankratz VS, Sando SB, Aasly JO, Barcikowska M, Wszolek ZK, Dickson DW, Graff-Radford NR, Petersen RC, van Duijn CM, Breteler MM, Ikram MA, DeStefano AL, Fitzpatrick AL, Lopez O, Launer LJ, Seshadri S, Berr C, Campion D, Epelbaum J, Dartigues JF, Tzourio C, Alperovitch A, Lathrop M, Feulner TM, Friedrich P, Riehle C, Krawczak M, Schreiber S, Mayhaus M, Nicolhaus S, Wagenpfeil S, Steinberg S, Stefansson H, Stefansson K, Snaedal J, Bjornsson S, Jonsson PV, Chouraki V, Genier-Boley B, Hiltunen M, Soininen H, Combarros O, Zelenika D, Delepine M, Bullido MJ, Pasquier F, Mateo I, FrankGarcia A, Porcellini E, Hanon O, Coto E, Alvarez V, Bosco P, Siciliano G, Mancuso M, Panza F, Solfrizzi V, Nacmias B, Sorbi S, Bossu P, Piccardi P, Arosio B, Annoni G, Seripa D, Pilotto A, Scarpini E, Galimberti D, Brice A, Hannequin D, Licastro F, Jones L, Holmans PA, Jonsson T, Riemenschneider M, Morgan K, Younkin SG, Owen MJ, O'Donovan M, Amouyel P, Williams J (2011) Common variants at ABCA7, MS4A6A/MS4A4E, EPHA1, CD33 and CD2AP are associated with Alzheimer's disease. Nat Genet 43, 429-435.

[147] Naj AC, Jun G, Beecham GW, Wang LS, Vardarajan BN, Buros J, Gallins PJ, Buxbaum JD, Jarvik GP, Crane PK, Larson EB, Bird TD, Boeve BF, Graff-Radford NR, De Jager PL, Evans D, Schneider JA, Carrasquillo MM, Ertekin-Taner N, Younkin SG, Cruchaga C, Kauwe JS, Nowotny P, Kramer P, Hardy J, Huentelman MJ, Myers AJ, Barmada MM, Demirci FY, Baldwin CT, Green RC, Rogaeva E, St 
George-Hyslop P, Arnold SE, Barber R, Beach T, Bigio EH, Bowen JD, Boxer A, Burke JR, Cairns NJ, Carlson CS, Carney RM, Carroll SL, Chui HC, Clark DG, Corneveaux J, Cotman CW, Cummings JL, DeCarli C, DeKosky ST, Diaz-Arrastia R, Dick M, Dickson DW, Ellis WG, Faber KM, Fallon KB, Farlow MR, Ferris S, Frosch MP, Galasko DR, Ganguli M, Gearing M, Geschwind DH, Ghetti B, Gilbert JR, Gilman S, Giordani B, Glass JD, Growdon JH, Hamilton RL, Harrell LE, Head E, Honig LS, Hulette CM, Hyman BT, Jicha GA, Jin LW, Johnson N, Karlawish J, Karydas A, Kaye JA, Kim R, Koo EH, Kowall NW, Lah JJ, Levey AI, Lieberman AP, Lopez OL, Mack WJ, Marson DC, Martiniuk F, Mash DC, Masliah E, McCormick WC, McCurry SM, McDavid AN, McKee AC, Mesulam M, Miller BL, Miller CA, Miller JW, Parisi JE, Perl DP, Peskind E, Petersen RC, Poon WW, Quinn JF, Rajbhandary RA, Raskind M, Reisberg B, Ringman JM, Roberson ED, Rosenberg RN, Sano M, Schneider LS, Seeley W, Shelanski ML, Slifer MA, Smith CD, Sonnen JA, Spina S, Stern RA, Tanzi RE, Trojanowski JQ, Troncoso JC, Van Deerlin VM, Vinters HV, Vonsattel JP, Weintraub S, Welsh-Bohmer KA, Williamson J, Woltjer RL, Cantwell LB, Dombroski BA, Beekly D, Lunetta KL, Martin ER, Kamboh MI, Saykin AJ, Reiman EM, Bennett DA, Morris JC, Montine TJ, Goate AM, Blacker D, Tsuang DW, Hakonarson H, Kukull WA, Foroud TM, Haines JL, Mayeux R, PericakVance MA, Farrer LA, Schellenberg GD (2011) Common variants at MS4A4/MS4A6E, CD2AP, CD33 and EPHA1 are associated with late-onset Alzheimer's disease. Nat Genet 43, 436-441.

[148] Krabbe G, Halle A, Matyash V, Rinnenthal JL, Eom GD, Bernhardt U, Miller KR, Prokop S, Kettenmann H, Heppner FL (2013) Functional impairment of microglia coincides with beta-amyloid deposition in mice with Alzheimer-like pathology. PLoS One 8 e60921, pp. 1-8. 
[149] Guerreiro R, Hardy J (2013) TREM2 and neurodegenerative disease. N Engl J Med 369, 1569-1570.

[150] Jonsson T, Stefansson H, Steinberg S, Jonsdottir I, Jonsson PV, Snaedal J, Bjornsson S, Huttenlocher J, Levey AI, Lah JJ, Rujescu D, Hampel H, Giegling I, Andreassen OA, Engedal K, Ulstein I, Djurovic S, Ibrahim-Verbaas C, Hofman A, Ikram MA, van Duijn CM, Thorsteinsdottir U, Kong A, Stefansson K (2013) Variant of TREM2 associated with the risk of Alzheimer's disease. N Engl J Med 368, 107-116.

[151] Bradshaw EM, Chibnik LB, Keenan BT, Ottoboni L, Raj T, Tang A, Rosenkrantz LL, Imboywa S, Lee M, Von Korff A, Morris MC, Evans DA, Johnson K, Sperling RA, Schneider JA, Bennett DA, De Jager PL (2013) CD33 Alzheimer's disease locus: altered monocyte function and amyloid biology. Nat Neurosci 16, 848-850.

[152] Griciuc A, Serrano-Pozo A, Parrado AR, Lesinski AN, Asselin CN, Mullin K, Hooli B, Choi SH, Hyman BT, Tanzi RE (2013) Alzheimer's disease risk gene CD33 inhibits microglial uptake of amyloid beta. Neuron 78, 631-643.

[153] Thambisetty M, An Y, Nalls M, Sojkova J, Swaminathan S, Zhou Y, Singleton AB, Wong DF, Ferrucci L, Saykin AJ, Resnick SM (2013) Effect of complement CR1 on brain amyloid burden during aging and its modification by APOE genotype. Biol Psychiatry 73, 422-428.

[154] Lucin KM, O'Brien CE, Bieri G, Czirr E, Mosher KI, Abbey RJ, Mastroeni DF, Rogers J, Spencer B, Masliah E, Wyss-Coray T (2013) Microglial beclin 1 regulates retromer trafficking and phagocytosis and is impaired in Alzheimer's disease. Neuron 79, $873-886$.

[155] Heneka MT, Sastre M, Dumitrescu-Ozimek L, Hanke A, Dewachter I, Kuiperi C, O'Banion K, Klockgether T, Van Leuven F, Landreth GE (2005) Acute treatment with 
the PPARgamma agonist pioglitazone and ibuprofen reduces glial inflammation and Abeta1-42 levels in APPV717I transgenic mice. Brain 128, 1442-1453.

[156] Heneka MT, Reyes-Irisarri E, Hull M, Kummer MP (2011) Impact and therapeutic potential of PPARs in Alzheimer's disease. Curr Neuropharmacol 9, 643-650.

[157] Yamanaka M, Ishikawa T, Griep A, Axt D, Kummer MP, Heneka MT (2012) PPARgamma/RXRalpha-induced and CD36-mediated microglial amyloid-beta phagocytosis results in cognitive improvement in amyloid precursor protein/presenilin 1 mice. J Neurosci 32, 17321-17331.

[158] Cramer PE, Cirrito JR, Wesson DW, Lee CY, Karlo JC, Zinn AE, Casali BT, Restivo JL, Goebel WD, James MJ, Brunden KR, Wilson DA, Landreth GE (2012) ApoEdirected therapeutics rapidly clear beta-amyloid and reverse deficits in AD mouse models. Science 335, 1503-1506.

[159] Szalardy L, Zadori D, Tanczos E, Simu M, Bencsik K, Vecsei L, Klivenyi P (2013) Elevated levels of PPAR-gamma in the cerebrospinal fluid of patients with multiple sclerosis. Neurosci Lett 554, 131-134.

[160] Szalardy L, Zadori D, Bencsik K, Vecsei L, Klivenyi P (2017) Unlike PPARgamma, neither other PPARs nor PGC-1alpha is elevated in the cerebrospinal fluid of patients with multiple sclerosis. Neurosci Lett 651, 128-133.

[161] Mandybur TI, Chuirazzi CC (1990) Astrocytes and the plaques of Alzheimer's disease. Neurology 40, 635-639.

[162] Akiyama H, Tooyama I, Kawamata T, Ikeda K, McGeer PL (1993) Morphological diversities of CD44 positive astrocytes in the cerebral cortex of normal subjects and patients with Alzheimer's disease. Brain Res 632, 249-259. 
[163] Kato S, Gondo T, Hoshii Y, Takahashi M, Yamada M, Ishihara T (1998) Confocal observation of senile plaques in Alzheimer's disease: senile plaque morphology and relationship between senile plaques and astrocytes. Pathol Int 48, 332-340.

[164] Pihlaja R, Koistinaho J, Kauppinen R, Sandholm J, Tanila H, Koistinaho M (2011) Multiple cellular and molecular mechanisms are involved in human Abeta clearance by transplanted adult astrocytes. Glia 59, 1643-1657.

[165] Wyss-Coray T, Loike JD, Brionne TC, Lu E, Anankov R, Yan F, Silverstein SC, Husemann J (2003) Adult mouse astrocytes degrade amyloid-beta in vitro and in situ. Nat Med 9, 453-457.

[166] Nagele RG, D'Andrea MR, Lee H, Venkataraman V, Wang HY (2003) Astrocytes accumulate A beta 42 and give rise to astrocytic amyloid plaques in Alzheimer disease brains. Brain Res 971, 197-209.

[167] Koistinaho M, Lin S, Wu X, Esterman M, Koger D, Hanson J, Higgs R, Liu F, Malkani S, Bales KR, Paul SM (2004) Apolipoprotein E promotes astrocyte colocalization and degradation of deposited amyloid-beta peptides. Nat Med 10, 719726.

[168] Terwel D, Steffensen KR, Verghese PB, Kummer MP, Gustafsson JA, Holtzman DM, Heneka MT (2011) Critical role of astroglial apolipoprotein E and liver X receptoralpha expression for microglial Abeta phagocytosis. J Neurosci 31, 7049-7059.

[169] Furman JL, Sama DM, Gant JC, Beckett TL, Murphy MP, Bachstetter AD, Van Eldik LJ, Norris CM (2012) Targeting astrocytes ameliorates neurologic changes in a mouse model of Alzheimer's disease. J Neurosci 32, 16129-16140.

[170] Griffin WS, Stanley LC, Ling C, White L, MacLeod V, Perrot LJ, White CL, 3rd, Araoz C (1989) Brain interleukin 1 and S-100 immunoreactivity are elevated in Down syndrome and Alzheimer disease. Proc Natl Acad Sci U S A 86, 7611-7615. 
[171] Cacabelos R, Alvarez XA, Fernandez-Novoa L, Franco A, Mangues R, Pellicer A, Nishimura T (1994) Brain interleukin-1 beta in Alzheimer's disease and vascular dementia. Methods Find Exp Clin Pharmacol 16, 141-151.

[172] Hull M, Berger M, Volk B, Bauer J (1996) Occurrence of interleukin-6 in cortical plaques of Alzheimer's disease patients may precede transformation of diffuse into neuritic plaques. Ann N Y Acad Sci 777, 205-212.

[173] Mehlhorn G, Hollborn M, Schliebs R (2000) Induction of cytokines in glial cells surrounding cortical beta-amyloid plaques in transgenic Tg2576 mice with Alzheimer pathology. Int J Dev Neurosci 18, 423-431.

[174] Abbas N, Bednar I, Mix E, Marie S, Paterson D, Ljungberg A, Morris C, Winblad B, Nordberg A, Zhu J (2002) Up-regulation of the inflammatory cytokines IFN-gamma and IL-12 and down-regulation of IL-4 in cerebral cortex regions of APP(SWE) transgenic mice. J Neuroimmunol 126, 50-57.

[175] Hampel H, Haslinger A, Scheloske M, Padberg F, Fischer P, Unger J, Teipel SJ, Neumann M, Rosenberg C, Oshida R, Hulette C, Pongratz D, Ewers M, Kretzschmar HA, Moller HJ (2005) Pattern of interleukin-6 receptor complex immunoreactivity between cortical regions of rapid autopsy normal and Alzheimer's disease brain. Eur Arch Psychiatry Clin Neurosci 255, 269-278.

[176] Patel NS, Paris D, Mathura V, Quadros AN, Crawford FC, Mullan MJ (2005) Inflammatory cytokine levels correlate with amyloid load in transgenic mouse models of Alzheimer's disease. J Neuroinflammation 2 9, pp. 1-8.

[177] Schwab C, Klegeris A, McGeer PL (2010) Inflammation in transgenic mouse models of neurodegenerative disorders. Biochim Biophys Acta 1802, 889-902.

[178] Morimoto K, Horio J, Satoh H, Sue L, Beach T, Arita S, Tooyama I, Konishi Y (2011) Expression profiles of cytokines in the brains of Alzheimer's disease (AD) patients 
compared to the brains of non-demented patients with and without increasing AD pathology. J Alzheimers Dis 25, 59-76.

[179] Vom Berg J, Prokop S, Miller KR, Obst J, Kalin RE, Lopategui-Cabezas I, Wegner A, Mair F, Schipke CG, Peters O, Winter Y, Becher B, Heppner FL (2012) Inhibition of IL-12/IL-23 signaling reduces Alzheimer's disease-like pathology and cognitive decline. Nat Med 18, 1812-1819.

[180] Sudduth TL, Schmitt FA, Nelson PT, Wilcock DM (2013) Neuroinflammatory phenotype in early Alzheimer's disease. Neurobiol Aging 34, 1051-1059.

[181] Heneka MT, Kummer MP, Stutz A, Delekate A, Schwartz S, Vieira-Saecker A, Griep A, Axt D, Remus A, Tzeng TC, Gelpi E, Halle A, Korte M, Latz E, Golenbock DT (2013) NLRP3 is activated in Alzheimer's disease and contributes to pathology in APP/PS1 mice. Nature 493, 674-678.

[182] Brosseron F, Krauthausen M, Kummer M, Heneka MT (2014) Body fluid cytokine levels in mild cognitive impairment and Alzheimer's disease: a comparative overview. Mol Neurobiol 50, 534-544.

[183] Tarkowski E, Andreasen N, Tarkowski A, Blennow K (2003) Intrathecal inflammation precedes development of Alzheimer's disease. J Neurol Neurosurg Psychiatry 74, 1200-1205.

[184] Buchhave P, Zetterberg H, Blennow K, Minthon L, Janciauskiene S, Hansson O (2010) Soluble TNF receptors are associated with Abeta metabolism and conversion to dementia in subjects with mild cognitive impairment. Neurobiol Aging 31, 18771884.

[185] Szalardy L, Zadori D, Klivenyi P, Vecsei L (2016) The role of cerebrospinal fluid biomarkers in the evolution of diagnostic criteria in alzheimer's disease: shortcomings in prodromal diagnosis. J Alzheimers Dis 53, 373-392. 
[186] Town T, Laouar Y, Pittenger C, Mori T, Szekely CA, Tan J, Duman RS, Flavell RA (2008) Blocking TGF-beta-Smad2/3 innate immune signaling mitigates Alzheimerlike pathology. Nat Med 14, 681-687.

[187] Chakrabarty P, Jansen-West K, Beccard A, Ceballos-Diaz C, Levites Y, Verbeeck C, Zubair AC, Dickson D, Golde TE, Das P (2010) Massive gliosis induced by interleukin-6 suppresses Abeta deposition in vivo: evidence against inflammation as a driving force for amyloid deposition. FASEB J 24, 548-559.

[188] Chakrabarty P, Herring A, Ceballos-Diaz C, Das P, Golde TE (2011) Hippocampal expression of murine TNFalpha results in attenuation of amyloid deposition in vivo. Mol Neurodegener 6 16, pp. 1-10.

[189] Chakrabarty P, Tianbai L, Herring A, Ceballos-Diaz C, Das P, Golde TE (2012) Hippocampal expression of murine IL-4 results in exacerbation of amyloid deposition. Mol Neurodegener 7 36, pp. 1-12.

[190] Chakrabarty P, Li A, Ceballos-Diaz C, Eddy JA, Funk CC, Moore B, DiNunno N, Rosario AM, Cruz PE, Verbeeck C, Sacino A, Nix S, Janus C, Price ND, Das P, Golde TE (2015) IL-10 alters immunoproteostasis in APP mice, increasing plaque burden and worsening cognitive behavior. Neuron 85, 519-533.

[191] Thal LJ, Ferris SH, Kirby L, Block GA, Lines CR, Yuen E, Assaid C, Nessly ML, Norman BA, Baranak CC, Reines SA (2005) A randomized, double-blind, study of rofecoxib in patients with mild cognitive impairment. Neuropsychopharmacology $\mathbf{3 0}$, 1204-1215.

[192] Martin BK, Szekely C, Brandt J, Piantadosi S, Breitner JC, Craft S, Evans D, Green R, Mullan M (2008) Cognitive function over time in the Alzheimer's Disease Antiinflammatory Prevention Trial (ADAPT): results of a randomized, controlled trial of naproxen and celecoxib. Arch Neurol 65, 896-905. 
[193] Leoutsakos JM, Muthen BO, Breitner JC, Lyketsos CG (2012) Effects of nonsteroidal anti-inflammatory drug treatments on cognitive decline vary by phase of preclinical Alzheimer disease: findings from the randomized controlled Alzheimer's Disease Anti-inflammatory Prevention Trial. Int J Geriatr Psychiatry 27, 364-374.

[194] Jaturapatporn D, Isaac MG, McCleery J, Tabet N (2012) Aspirin, steroidal and nonsteroidal anti-inflammatory drugs for the treatment of Alzheimer's disease. Cochrane Database Syst Rev, CD006378.

[195] ADAPT-FS RG (2015) Follow-up evaluation of cognitive function in the randomized Alzheimer's Disease Anti-inflammatory Prevention Trial and its Follow-up Study. Alzheimers Dement 11, 216-225.

[196] Montine TJ, Sidell KR, Crews BC, Markesbery WR, Marnett LJ, Roberts LJ, 2nd, Morrow JD (1999) Elevated CSF prostaglandin E2 levels in patients with probable AD. Neurology 53, 1495-1498.

[197] Yan Q, Zhang J, Liu H, Babu-Khan S, Vassar R, Biere AL, Citron M, Landreth G (2003) Anti-inflammatory drug therapy alters beta-amyloid processing and deposition in an animal model of Alzheimer's disease. J Neurosci 23, 7504-7509.

[198] Shie FS, Breyer RM, Montine TJ (2005) Microglia lacking E Prostanoid Receptor subtype 2 have enhanced Abeta phagocytosis yet lack Abeta-activated neurotoxicity. Am J Pathol 166, 1163-1172.

[199] Combrinck M, Williams J, De Berardinis MA, Warden D, Puopolo M, Smith AD, Minghetti L (2006) Levels of CSF prostaglandin E2, cognitive decline, and survival in Alzheimer's disease. J Neurol Neurosurg Psychiatry 77, 85-88.

[200] Johansson JU, Woodling NS, Wang Q, Panchal M, Liang X, Trueba-Saiz A, Brown HD, Mhatre SD, Loui T, Andreasson KI (2015) Prostaglandin signaling suppresses 
beneficial microglial function in Alzheimer's disease models. J Clin Invest 125, 350364.

[201] Wolf H (1974) The effect of hormones and vitamin B6 on urinary excretion of metabolites of the kynurenine pathway. Scand J Clin Lab Invest Suppl 136, 1-186.

[202] Zadori D, Klivenyi P, Plangar I, Toldi J, Vecsei L (2011) Endogenous neuroprotection in chronic neurodegenerative disorders: with particular regard to the kynurenines. $J$ Cell Mol Med 15, 701-717.

[203] Gonzalez Esquivel D, Ramirez-Ortega D, Pineda B, Castro N, Rios C, Perez de la Cruz V (2017) Kynurenine pathway metabolites and enzymes involved in redox reactions. Neuropharmacology 112, 331-345.

[204] Klivenyi P, Toldi J, Vecsei L (2004) Kynurenines in neurodegenerative disorders: therapeutic consideration. Adv Exp Med Biol 541, 169-183.

[205] Zadori D, Klivenyi P, Vamos E, Fulop F, Toldi J, Vecsei L (2009) Kynurenines in chronic neurodegenerative disorders: future therapeutic strategies. J Neural Transm (Vienna) 116, 1403-1409.

[206] Kincses ZT, Toldi J, Vecsei L (2010) Kynurenines, neurodegeneration and Alzheimer's disease. J Cell Mol Med 14, 2045-2054.

[207] Plangar I, Zadori D, Klivenyi P, Toldi J, Vecsei L (2011) Targeting the kynurenine pathway-related alterations in Alzheimer's disease: a future therapeutic strategy. $J$ Alzheimers Dis 24 Suppl 2, 199-209.

[208] Stone TW (1993) Neuropharmacology of quinolinic and kynurenic acids. Pharmacol $\operatorname{Rev}$ 45, 309-379.

[209] Fulop F, Szatmari I, Vamos E, Zadori D, Toldi J, Vecsei L (2009) Syntheses, transformations and pharmaceutical applications of kynurenic acid derivatives. Curr Med Chem 16, 4828-4842. 
[210] Schwarcz R, Bruno JP, Muchowski PJ, Wu HQ (2012) Kynurenines in the mammalian brain: when physiology meets pathology. Nat Rev Neurosci 13, 465-477.

[211] Zadori D, Veres G, Szalardy L, Klivenyi P, Fulop F, Toldi J, Vecsei L (2016) Inhibitors of the kynurenine pathway as neurotherapeutics: a patent review (20122015). Expert Opin Ther Pat 26, 815-832.

[212] Widner B, Leblhuber F, Walli J, Tilz GP, Demel U, Fuchs D (1999) Degradation of tryptophan in neurodegenerative disorders. Adv Exp Med Biol 467, 133-138.

[213] Widner B, Leblhuber F, Walli J, Tilz GP, Demel U, Fuchs D (2000) Tryptophan degradation and immune activation in Alzheimer's disease. J Neural Transm (Vienna) 107, 343-353.

[214] Guillemin GJ, Brew BJ, Noonan CE, Takikawa O, Cullen KM (2005) Indoleamine 2,3 dioxygenase and quinolinic acid immunoreactivity in Alzheimer's disease hippocampus. Neuropathol Appl Neurobiol 31, 395-404.

[215] Wu W, Nicolazzo JA, Wen L, Chung R, Stankovic R, Bao SS, Lim CK, Brew BJ, Cullen KM, Guillemin GJ (2013) Expression of tryptophan 2,3-dioxygenase and production of kynurenine pathway metabolites in triple transgenic mice and human Alzheimer's disease brain. PLoS One 8 e59749, pp. 1-11.

[216] Bonda DJ, Mailankot M, Stone JG, Garrett MR, Staniszewska M, Castellani RJ, Siedlak SL, Zhu X, Lee HG, Perry G, Nagaraj RH, Smith MA (2010) Indoleamine 2,3-dioxygenase and 3-hydroxykynurenine modifications are found in the neuropathology of Alzheimer's disease. Redox Rep 15, 161-168.

[217] Guillemin GJ, Smythe GA, Veas LA, Takikawa O, Brew BJ (2003) A beta 1-42 induces production of quinolinic acid by human macrophages and microglia. Neuroreport 14, 2311-2315. 
[218] Dykens JA, Sullivan SG, Stern A (1987) Oxidative reactivity of the tryptophan metabolites 3-hydroxyanthranilate, cinnabarinate, quinolinate and picolinate. Biochem Pharmacol 36, 211-217.

[219] Jhamandas K, Boegman RJ, Beninger RJ, Bialik M (1990) Quinolinate-induced cortical cholinergic damage: modulation by tryptophan metabolites. Brain Res $\mathbf{5 2 9}$, 185-191.

[220] Eastman CL, Guilarte TR (1990) The role of hydrogen peroxide in the in vitro cytotoxicity of 3-hydroxykynurenine. Neurochem Res 15, 1101-1107.

[221] Okuda S, Nishiyama N, Saito H, Katsuki H (1998) 3-Hydroxykynurenine, an endogenous oxidative stress generator, causes neuronal cell death with apoptotic features and region selectivity. J Neurochem 70, 299-307.

[222] Colin-Gonzalez AL, Maldonado PD, Santamaria A (2013) 3-Hydroxykynurenine: an intriguing molecule exerting dual actions in the central nervous system. Neurotoxicology 34, 189-204.

[223] Colin-Gonzalez AL, Maya-Lopez M, Pedraza-Chaverri J, Ali SF, Chavarria A, Santamaria A (2014) The Janus faces of 3-hydroxykynurenine: dual redox modulatory activity and lack of neurotoxicity in the rat striatum. Brain Res 1589, 1-14.

[224] Notarangelo FM, Wu HQ, Macherone A, Graham DR, Schwarcz R (2012) Gas chromatography/tandem mass spectrometry detection of extracellular kynurenine and related metabolites in normal and lesioned rat brain. Anal Biochem 421, 573-581.

[225] Reyes-Ocampo J, Ramirez-Ortega D, Cervantes GI, Pineda B, Balderas PM, Gonzalez-Esquivel D, Sanchez-Chapul L, Lugo-Huitron R, Silva-Adaya D, Rios C, Jimenez-Anguiano A, Perez-de la Cruz V (2015) Mitochondrial dysfunction related to cell damage induced by 3-hydroxykynurenine and 3-hydroxyanthranilic acid: Non- 
dependent-effect of early reactive oxygen species production. Neurotoxicology 50, 8191.

[226] Heyes MP, Achim CL, Wiley CA, Major EO, Saito K, Markey SP (1996) Human microglia convert L-tryptophan into the neurotoxin quinolinic acid. Biochem J 320, 595-597.

[227] Espey MG, Chernyshev ON, Reinhard JF, Jr., Namboodiri MA, Colton CA (1997) Activated human microglia produce the excitotoxin quinolinic acid. Neuroreport $\mathbf{8}$, 431-434.

[228] Guillemin GJ, Kerr SJ, Smythe GA, Smith DG, Kapoor V, Armati PJ, Croitoru J, Brew BJ (2001) Kynurenine pathway metabolism in human astrocytes: a paradox for neuronal protection. J Neurochem 78, 842-853.

[229] Guillemin GJ, Smythe G, Takikawa O, Brew BJ (2005) Expression of indoleamine 2,3-dioxygenase and production of quinolinic acid by human microglia, astrocytes, and neurons. Glia 49, 15-23.

[230] Pearson SJ, Reynolds GP (1992) Increased brain concentrations of a neurotoxin, 3hydroxykynurenine, in Huntington's disease. Neurosci Lett 144, 199-201.

[231] Baran H, Jellinger K, Deecke L (1999) Kynurenine metabolism in Alzheimer's disease. J Neural Transm (Vienna) 106, 165-181.

[232] Schwarz MJ, Guillemin GJ, Teipel SJ, Buerger K, Hampel H (2013) Increased 3hydroxykynurenine serum concentrations differentiate Alzheimer's disease patients from controls. Eur Arch Psychiatry Clin Neurosci 263, 345-352.

[233] Duleu S, Mangas A, Sevin F, Veyret B, Bessede A, Geffard M (2010) Circulating antibodies to IDO/THO pathway metabolites in Alzheimer's disease. Int J Alzheimers Dis 2010 Article ID 501541, pp. 1-6. 
[234] Gulaj E, Pawlak K, Bien B, Pawlak D (2010) Kynurenine and its metabolites in Alzheimer's disease patients. Adv Med Sci 55, 204-211.

[235] Tohgi H, Abe T, Takahashi S, Kimura M, Takahashi J, Kikuchi T (1992)

Concentrations of serotonin and its related substances in the cerebrospinal fluid in patients with Alzheimer type dementia. Neurosci Lett 141, 9-12.

[236] Browne TC, McQuillan K, McManus RM, O'Reilly JA, Mills KH, Lynch MA (2013) IFN-gamma production by amyloid beta-specific Th1 cells promotes microglial activation and increases plaque burden in a mouse model of Alzheimer's disease. $J$ Immunol 190, 2241-2251.

[237] Scolding NJ, Joseph F, Kirby PA, Mazanti I, Gray F, Mikol J, Ellison D, Hilton DA, Williams TL, MacKenzie JM, Xuereb JH, Love S (2005) Abeta-related angiitis: primary angiitis of the central nervous system associated with cerebral amyloid angiopathy. Brain 128, 500-515.

[238] de Carvalho LP, Bochet P, Rossier J (1996) The endogenous agonist quinolinic acid and the non endogenous homoquinolinic acid discriminate between NMDAR2 receptor subunits. Neurochem Int 28, 445-452.

[239] Stone TW, Perkins MN (1981) Quinolinic acid: a potent endogenous excitant at amino acid receptors in CNS. Eur J Pharmacol 72, 411-412.

[240] Connick JH, Stone TW (1988) Quinolinic acid effects on amino acid release from the rat cerebral cortex in vitro and in vivo. Br J Pharmacol 93, 868-876.

[241] Tavares RG, Tasca CI, Santos CE, Alves LB, Porciuncula LO, Emanuelli T, Souza DO (2002) Quinolinic acid stimulates synaptosomal glutamate release and inhibits glutamate uptake into astrocytes. Neurochem Int 40, 621-627. 
[242] Rahman A, Ting K, Cullen KM, Braidy N, Brew BJ, Guillemin GJ (2009) The excitotoxin quinolinic acid induces tau phosphorylation in human neurons. PLoS One 4 e6344, pp. 1-15.

[243] Rios C, Santamaria A (1991) Quinolinic acid is a potent lipid peroxidant in rat brain homogenates. Neurochem Res 16, 1139-1143.

[244] Behan WM, McDonald M, Darlington LG, Stone TW (1999) Oxidative stress as a mechanism for quinolinic acid-induced hippocampal damage: protection by melatonin and deprenyl. Br J Pharmacol 128, 1754-1760.

[245] Montine TJ, Neely MD, Quinn JF, Beal MF, Markesbery WR, Roberts LJ, Morrow JD (2002) Lipid peroxidation in aging brain and Alzheimer's disease. Free Radic Biol Med 33, 620-626.

[246] St'astny F, Lisy V, Mares V, Lisa V, Balcar VJ, Santamaria A (2004) Quinolinic acid induces NMDA receptor-mediated lipid peroxidation in rat brain microvessels. Redox $\operatorname{Rep}$ 9, 229-233.

[247] Stipek S, Stastny F, Platenik J, Crkovska J, Zima T (1997) The effect of quinolinate on rat brain lipid peroxidation is dependent on iron. Neurochem Int 30, 233-237.

[248] Rodriguez-Martinez E, Camacho A, Maldonado PD, Pedraza-Chaverri J, Santamaria D, Galvan-Arzate S, Santamaria A (2000) Effect of quinolinic acid on endogenous antioxidants in rat corpus striatum. Brain Res 858, 436-439.

[249] Ganzella M, Jardim FM, Boeck CR, Vendite D (2006) Time course of oxidative events in the hippocampus following intracerebroventricular infusion of quinolinic acid in mice. Neurosci Res 55, 397-402.

[250] Braidy N, Grant R, Adams S, Guillemin GJ (2010) Neuroprotective effects of naturally occurring polyphenols on quinolinic acid-induced excitotoxicity in human neurons. FEBS J 277, 368-382. 
[251] Perez-De La Cruz V, Elinos-Calderon D, Carrillo-Mora P, Silva-Adaya D, Konigsberg M, Moran J, Ali SF, Chanez-Cardenas ME, Perez-De La Cruz G, Santamaria A (2010) Time-course correlation of early toxic events in three models of striatal damage: modulation by proteases inhibition. Neurochem Int 56, 834-842.

[252] Lugo-Huitron R, Ugalde Muniz P, Pineda B, Pedraza-Chaverri J, Rios C, Perez-de la Cruz V (2013) Quinolinic acid: an endogenous neurotoxin with multiple targets. Oxid Med Cell Longev 2013, 104024.

[253] Moroni F, Lombardi G, Robitaille Y, Etienne P (1986) Senile dementia and Alzheimer's disease: lack of changes of the cortical content of quinolinic acid. Neurobiol Aging 7, 249-253.

[254] Sofic E, Halket J, Przyborowska A, Riederer P, Beckmann H, Sandler M, Jellinger K (1989) Brain quinolinic acid in Alzheimer's dementia. Eur Arch Psychiatry Neurol Sci 239, $177-179$.

[255] Mourdian MM, Heyes MP, Pan JB, Heuser IJ, Markey SP, Chase TN, Mouradian MM (1989) No changes in central quinolinic acid levels in Alzheimer's disease. Neurosci Lett 105, 233-238.

[256] Guillemin GJ, Brew BJ, Noonan CE, Knight TG, Smythe GA, Cullen KM (2007) Mass spectrometric detection of quinolinic acid in microdissected Alzheimer's disease plaques. Int Congr Ser 1304, 404-408.

[257] Heyes MP, Saito K, Crowley JS, Davis LE, Demitrack MA, Der M, Dilling LA, Elia J, Kruesi MJ, Lackner A, et al. (1992) Quinolinic acid and kynurenine pathway metabolism in inflammatory and non-inflammatory neurological disease. Brain 115, 1249-1273.

[258] Terness P, Bauer TM, Rose L, Dufter C, Watzlik A, Simon H, Opelz G (2002) Inhibition of allogeneic $\mathrm{T}$ cell proliferation by indoleamine 2,3-dioxygenase- 
expressing dendritic cells: mediation of suppression by tryptophan metabolites. J Exp Med 196, 447-457.

[259] Fallarino F, Grohmann U, Vacca C, Bianchi R, Orabona C, Spreca A, Fioretti MC, Puccetti P (2002) T cell apoptosis by tryptophan catabolism. Cell Death Differ 9 , 1069-1077.

[260] Bauer TM, Jiga LP, Chuang JJ, Randazzo M, Opelz G, Terness P (2005) Studying the immunosuppressive role of indoleamine 2,3-dioxygenase: tryptophan metabolites suppress rat allogeneic T-cell responses in vitro and in vivo. Transpl Int 18, 95-100.

[261] Guillemin GJ, Croitoru-Lamoury J, Dormont D, Armati PJ, Brew BJ (2003) Quinolinic acid upregulates chemokine production and chemokine receptor expression in astrocytes. Glia $\mathbf{4 1}, 371-381$.

[262] Guillemin GJ, Wang L, Brew BJ (2005) Quinolinic acid selectively induces apoptosis of human astrocytes: potential role in AIDS dementia complex. J Neuroinflammation 2 16, pp. 1-6.

[263] Ting KK, Brew BJ, Guillemin GJ (2009) Effect of quinolinic acid on human astrocytes morphology and functions: implications in Alzheimer's disease. $J$ Neuroinflammation 6 36, pp. 1-13.

[264] Wu HQ, Lee SC, Schwarcz R (2000) Systemic administration of 4-chlorokynurenine prevents quinolinate neurotoxicity in the rat hippocampus. Eur J Pharmacol 390, 267274.

[265] Parli CJ, Krieter P, Schmidt B (1980) Metabolism of 6-chlorotryptophan to 4-chloro3-hydroxyanthranilic acid: a potent inhibitor of 3-hydroxyanthranilic acid oxidase. Arch Biochem Biophys 203, 161-166. 
[266] Guidetti P, Wu HQ, Schwarcz R (2000) In situ produced 7-chlorokynurenate provides protection against quinolinate- and malonate-induced neurotoxicity in the rat striatum. Exp Neurol 163, 123-130.

[267] Zadori D, Klivenyi P, Szalardy L, Fulop F, Toldi J, Vecsei L (2012) Mitochondrial disturbances, excitotoxicity, neuroinflammation and kynurenines: novel therapeutic strategies for neurodegenerative disorders. J Neurol Sci 322, 187-191.

[268] Heredi J, Berko AM, Jankovics F, Iwamori T, Iwamori N, Ono E, Horvath S, Kis Z, Toldi J, Vecsei L, Gellert L (2017) Astrocytic and neuronal localization of kynurenine aminotransferase-2 in the adult mouse brain. Brain Struct Funct 222, 1663-1672.

[269] Perkins MN, Stone TW (1982) An iontophoretic investigation of the actions of convulsant kynurenines and their interaction with the endogenous excitant quinolinic acid. Brain Res 247, 184-187.

[270] Kessler M, Terramani T, Lynch G, Baudry M (1989) A glycine site associated with Nmethyl-D-aspartic acid receptors: characterization and identification of a new class of antagonists. J Neurochem 52, 1319-1328.

[271] Swartz KJ, During MJ, Freese A, Beal MF (1990) Cerebral synthesis and release of kynurenic acid: an endogenous antagonist of excitatory amino acid receptors. $J$ Neurosci 10, 2965-2973.

[272] Linderholm K, Powell S, Olsson E, Holtze M, Snodgrass R, Erhardt S (2010) Role of the NMDA-receptor in Prepulse Inhibition in the Rat. Int J Tryptophan Res 3, 1-12.

[273] Prescott C, Weeks AM, Staley KJ, Partin KM (2006) Kynurenic acid has a dual action on AMPA receptor responses. Neurosci Lett 402, 108-112.

[274] Rozsa E, Robotka H, Vecsei L, Toldi J (2008) The Janus-face kynurenic acid. J Neural Transm (Vienna) 115, 1087-1091. 
[275] Goda K, Hamane Y, Kishimoto R, Ogishi Y (1999) Radical scavenging properties of tryptophan metabolites. Estimation of their radical reactivity. Adv Exp Med Biol 467, 397-402.

[276] Hardeland R, Zsizsik BK, Poeggeler B, Fuhrberg B, Holst S, Coto-Montes A (1999) Indole-3-pyruvic and -propionic acids, kynurenic acid, and related metabolites as luminophores and free-radical scavengers. Adv Exp Med Biol 467, 389-395.

[277] Lugo-Huitron R, Blanco-Ayala T, Ugalde-Muniz P, Carrillo-Mora P, PedrazaChaverri J, Silva-Adaya D, Maldonado PD, Torres I, Pinzon E, Ortiz-Islas E, Lopez T, Garcia E, Pineda B, Torres-Ramos M, Santamaria A, La Cruz VP (2011) On the antioxidant properties of kynurenic acid: free radical scavenging activity and inhibition of oxidative stress. Neurotoxicol Teratol 33, 538-547.

[278] Fukuda A, Muramatsu K, Okabe A, Shimano Y, Hida H, Fujimoto I, Nishino H (1998) NMDA receptor-mediated differential laminar susceptibility to the intracellular $\mathrm{Ca} 2+$ accumulation induced by oxygen-glucose deprivation in rat neocortical slices. $J$ Neurophysiol 79, 430-438.

[279] Csillik A, Knyihar E, Okuno E, Krisztin-Peva B, Csillik B, Vecsei L (2002) Effect of 3-nitropropionic acid on kynurenine aminotransferase in the rat brain. Exp Neurol 177, 233-241.

[280] Luchowski P, Luchowska E, Turski WA, Urbanska EM (2002) 1-Methyl-4phenylpyridinium and 3-nitropropionic acid diminish cortical synthesis of kynurenic acid via interference with kynurenine aminotransferases in rats. Neurosci Lett 330, 4952.

[281] Wang J, Simonavicius N, Wu X, Swaminath G, Reagan J, Tian H, Ling L (2006) Kynurenic acid as a ligand for orphan G protein-coupled receptor GPR35. J Biol Chem 281, 22021-22028. 
[282] Klein C, Patte-Mensah C, Taleb O, Bourguignon JJ, Schmitt M, Bihel F, Maitre M, Mensah-Nyagan AG (2013) The neuroprotector kynurenic acid increases neuronal cell survival through neprilysin induction. Neuropharmacology 70, 254-260.

[283] Park MH, Lee JK, Choi S, Ahn J, Jin HK, Park JS, Bae JS (2013) Recombinant soluble neprilysin reduces amyloid-beta accumulation and improves memory impairment in Alzheimer's disease mice. Brain Res 1529, 113-124.

[284] Huttenrauch M, Baches S, Gerth J, Bayer TA, Weggen S, Wirths O (2015) Neprilysin deficiency alters the neuropathological and behavioral phenotype in the 5XFAD mouse model of Alzheimer's disease. J Alzheimers Dis 44, 1291-1302.

[285] Guillemin GJ, Williams KR, Smith DG, Smythe GA, Croitoru-Lamoury J, Brew BJ (2003) Quinolinic acid in the pathogenesis of Alzheimer's disease. Adv Exp Med Biol 527, $167-176$.

[286] Steiner L, Gold M, Mengel D, Dodel R, Bach JP (2014) The endogenous alpha7 nicotinic acetylcholine receptor antagonist kynurenic acid modulates amyloid-betainduced inflammation in BV-2 microglial cells. J Neurol Sci 344, 94-99.

[287] Maaetoft-Udsen K, Shimoda LM, Frokiaer H, Turner H (2012) Aryl hydrocarbon receptor ligand effects in RBL2H3 cells. J Immunotoxicol 9, 327-337.

[288] DiNatale BC, Murray IA, Schroeder JC, Flaveny CA, Lahoti TS, Laurenzana EM, Omiecinski CJ, Perdew GH (2010) Kynurenic acid is a potent endogenous aryl hydrocarbon receptor ligand that synergistically induces interleukin-6 in the presence of inflammatory signaling. Toxicol Sci 115, 89-97.

[289] Beal MF, Matson WR, Storey E, Milbury P, Ryan EA, Ogawa T, Bird ED (1992) Kynurenic acid concentrations are reduced in Huntington's disease cerebral cortex. $J$ Neurol Sci 108, 80-87. 
[290] Francis PT, Sims NR, Procter AW, Bowen DM (1993) Cortical pyramidal neurone loss may cause glutamatergic hypoactivity and cognitive impairment in Alzheimer's disease: investigative and therapeutic perspectives. J Neurochem 60, 1589-1604.

[291] Ulas J, Weihmuller FB, Brunner LC, Joyce JN, Marshall JF, Cotman CW (1994) Selective increase of NMDA-sensitive glutamate binding in the striatum of Parkinson's disease, Alzheimer's disease, and mixed Parkinson's disease/Alzheimer's disease patients: an autoradiographic study. J Neurosci 14, 6317-6324.

[292] Knyihar-Csillik E, Okuno E, Vecsei L (1999) Effects of in vivo sodium azide administration on the immunohistochemical localization of kynurenine aminotransferase in the rat brain. Neuroscience 94, 269-277.

[293] Hartai Z, Juhasz A, Rimanoczy A, Janaky T, Donko T, Dux L, Penke B, Toth GK, Janka Z, Kalman J (2007) Decreased serum and red blood cell kynurenic acid levels in Alzheimer's disease. Neurochem Int 50, 308-313.

[294] Wennstrom M, Nielsen HM, Orhan F, Londos E, Minthon L, Erhardt S (2014) Kynurenic acid levels in cerebrospinal fluid from patients with Alzheimer's disease or dementia with Lewy bodies. Int J Tryptophan Res 7, 1-7.

[295] Fitzjohn SM, Morton RA, Kuenzi F, Rosahl TW, Shearman M, Lewis H, Smith D, Reynolds DS, Davies CH, Collingridge GL, Seabrook GR (2001) Age-related impairment of synaptic transmission but normal long-term potentiation in transgenic mice that overexpress the human APP695SWE mutant form of amyloid precursor protein. J Neurosci 21, 4691-4698.

[296] Carrillo-Mora P, Mendez-Cuesta LA, Perez-De La Cruz V, Fortoul-van Der Goes TI, Santamaria A (2010) Protective effect of systemic L-kynurenine and probenecid administration on behavioural and morphological alterations induced by toxic soluble amyloid beta (25-35) in rat hippocampus. Behav Brain Res 210, 240-250. 
[297] Robotka H, Nemeth H, Somlai C, Vecsei L, Toldi J (2005) Systemically administered glucosamine-kynurenic acid, but not pure kynurenic acid, is effective in decreasing the evoked activity in area CA1 of the rat hippocampus. Eur J Pharmacol 513, 75-80.

[298] Deora GS, Kantham S, Chan S, Dighe SN, Veliyath SK, McColl G, Parat MO, McGeary RP, Ross BP (2017) Multifunctional analogs of kynurenic acid for the treatment of Alzheimer's disease: Synthesis, pharmacology, and molecular modeling studies. ACS Chem Neurosci, in press.

[299] Li L, Sengupta A, Haque N, Grundke-Iqbal I, Iqbal K (2004) Memantine inhibits and reverses the Alzheimer type abnormal hyperphosphorylation of tau and associated neurodegeneration. FEBS Lett 566, 261-269.

[300] Vecsei L, Beal MF (1991) Comparative behavioral and pharmacological studies with centrally administered kynurenine and kynurenic acid in rats. Eur J Pharmacol 196, 239-246.

[301] Shepard PD, Joy B, Clerkin L, Schwarcz R (2003) Micromolar brain levels of kynurenic acid are associated with a disruption of auditory sensory gating in the rat. Neuropsychopharmacology 28, 1454-1462.

[302] Erhardt S, Schwieler L, Emanuelsson C, Geyer M (2004) Endogenous kynurenic acid disrupts prepulse inhibition. Biol Psychiatry 56, 255-260.

[303] Chess AC, Simoni MK, Alling TE, Bucci DJ (2007) Elevations of endogenous kynurenic acid produce spatial working memory deficits. Schizophr Bull 33, 797-804.

[304] Chess AC, Landers AM, Bucci DJ (2009) L-kynurenine treatment alters contextual fear conditioning and context discrimination but not cue-specific fear conditioning. Behav Brain Res 201, 325-331.

[305] Potter MC, Elmer GI, Bergeron R, Albuquerque EX, Guidetti P, Wu HQ, Schwarcz R (2010) Reduction of endogenous kynurenic acid formation enhances extracellular 
glutamate, hippocampal plasticity, and cognitive behavior. Neuropsychopharmacology 35, 1734-1742.

[306] Pocivavsek A, Wu HQ, Potter MC, Elmer GI, Pellicciari R, Schwarcz R (2011) Fluctuations in endogenous kynurenic acid control hippocampal glutamate and memory. Neuropsychopharmacology 36, 2357-2367.

[307] Mony L, Kew JN, Gunthorpe MJ, Paoletti P (2009) Allosteric modulators of NR2Bcontaining NMDA receptors: molecular mechanisms and therapeutic potential. $\mathrm{Br} J$ Pharmacol 157, 1301-1317.

[308] Szalardy L, Zadori D, Toldi J, Fulop F, Klivenyi P, Vecsei L (2012) Manipulating kynurenic acid levels in the brain - on the edge between neuroprotection and cognitive dysfunction. Curr Top Med Chem 12, 1797-1806.

[309] Borza I, Kolok S, Galgoczy K, Gere A, Horvath C, Farkas S, Greiner I, Domany G (2007) Kynurenic acid amides as novel NR2B selective NMDA receptor antagonists. Bioorg Med Chem Lett 17, 406-409.

[310] Zadori D, Nyiri G, Szonyi A, Szatmari I, Fulop F, Toldi J, Freund TF, Vecsei L, Klivenyi P (2011) Neuroprotective effects of a novel kynurenic acid analogue in a transgenic mouse model of Huntington's disease. J Neural Transm (Vienna) 118, 865875.

[311] Gellert L, Fuzik J, Goblos A, Sarkozi K, Marosi M, Kis Z, Farkas T, Szatmari I, Fulop F, Vecsei L, Toldi J (2011) Neuroprotection with a new kynurenic acid analog in the four-vessel occlusion model of ischemia. Eur J Pharmacol 667, 182-187.

[312] Nagy K, Plangar I, Tuka B, Gellert L, Varga D, Demeter I, Farkas T, Kis Z, Marosi M, Zadori D, Klivenyi P, Fulop F, Szatmari I, Vecsei L, Toldi J (2011) Synthesis and biological effects of some kynurenic acid analogs. Bioorg Med Chem 19, 7590-7596. 
[313] Gellert L, Varga D, Ruszka M, Toldi J, Farkas T, Szatmari I, Fulop F, Vecsei L, Kis Z (2012) Behavioural studies with a newly developed neuroprotective KYNA-amide. $J$ Neural Transm (Vienna) 119, 165-172.

[314] Varga D, Heredi J, Kanvasi Z, Ruszka M, Kis Z, Ono E, Iwamori N, Iwamori T, Takakuwa H, Vecsei L, Toldi J, Gellert L (2015) Systemic L-kynurenine sulfate administration disrupts object recognition memory, alters open field behavior and decreases c-Fos immunopositivity in C57B1/6 mice. Front Behav Neurosci 9, 157.

[315] Demeter I, Nagy K, Farkas T, Kis Z, Kocsis K, Knapp L, Gellert L, Fulop F, Vecsei L, Toldi J (2013) Paradox effects of kynurenines on LTP induction in the Wistar rat. An in vivo study. Neurosci Lett 553, 138-141.

[316] Sas K, Robotka H, Toldi J, Vecsei L (2007) Mitochondria, metabolic disturbances, oxidative stress and the kynurenine system, with focus on neurodegenerative disorders. J Neurol Sci 257, 221-239.

[317] Szalardy L, Klivenyi P, Zadori D, Fulop F, Toldi J, Vecsei L (2012) Mitochondrial disturbances, tryptophan metabolites and neurodegeneration: medicinal chemistry aspects. Curr Med Chem 19, 1899-1920.

[318] Zadori D, Veres G, Szalardy L, Klivenyi P, Toldi J, Vecsei L (2014) Glutamatergic dysfunctioning in Alzheimer's disease and related therapeutic targets. J Alzheimers Dis 42 Suppl 3, S177-187.

\section{FIGURE CAPTIONS}

Figure 1. The schematic depiction of the kynurenine pathway of tryptophan metabolism.

Figure 2. The possible implications of kynurenine pathway metabolites in mitochondrial dysfunction and glutamate excitotoxicity. 3-OH-ANA: 3-hydroxy-anthranilic acid, 3-OH-L- 
KYN: 3-hydroxy-L-kynurenine, cc.: concentration, KYNA: kynurenic acid, LTD: long-term depression, LTP: long-term potentiation, QUIN: quinolinic acid

Figure 3. The possible implications of kynurenine pathway metabolites in neuroinflammation in $\mathrm{AD}$. A $\beta$ triggers IDO induction in microglia/macrophages and astrocytes, with consequent activation of the kynurenine pathway. Microglia/macrophages preferentially metabolize LKYN through the KMO branch, giving rise to 3-OH-ANA, 3-OH-L-KYN, and QUIN. 3-OHANA and 3-OH-L-KYN are implicated in oxidative stress and suppression of target-specific immune response, and their exact role in AD pathogenesis is not well established. QUIN is a neurotoxic metabolite abundantly present in hallmark pathologies such as amyloid plaques and neurofibrillary tangles, and can contribute to $\mathrm{AD}$ pathology by promoting neurodegeneration, tau hyperphosphorylation, lipid peroxidation, astrocyte dysfunction, and monocyte recruitment. Astrocytes preferentially metabolize L-KYN through the transaminase branch, giving rise to KYNA. KYNA may act as an endogenous neuroprotectant due to its anti-excitotoxic, antioxidant, $\mathrm{A} \beta$ degradation-promoting, and anti-inflammatory properties, with the latter being attributable to its ability to downregulate TNF $\alpha$ and IL-6 production in microglia/macrophages. 3-OH-ANA: 3-hydroxy-anthranilic acid, 3-OH-L-KYN: 3-hydroxyL-kynurenine, A $\beta$ : Amyloid-beta, IL-6: interleukin-6, KATs: kynurenine aminotransferases, KMO: kynurenine 3-monooxygenase, KYNA: kynurenic acid, IDO: indolamine 2,3dioxygenase, TNF $\alpha$ : tumor necrosis factor alpha QUIN: quinolinic acid 


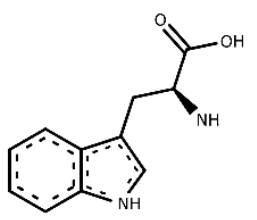

L-tryptophan

ndolamine 2,3-dioxygenase tryptophan 2,3-dioxygenase<smiles>Nc1c(O)cccc1C(=O)C[C@H](N)C(=O)O</smiles>

3-hydroxy-L-kynurenine

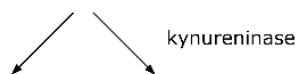

xanthurenic acid

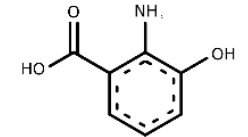

3-hydroxyanthranilic acid

kynurenine 3-monooxygenase

kynureninase

anthranilate 3,4-dioxygenase<smiles>Nc1ccccc1C(=O)C[C@H](N)C(=O)O</smiles>

L-kynurenine

kynureninase

anthranilic acid

anthranilate

3-monooxygenase $\underset{\text { kynurenine }}{\longrightarrow}$ aminotransferase<smiles>O=C(O)c1cc(O)c2ccccc2n1</smiles>

kynurenic acid

picolinic acid

Figure 1 


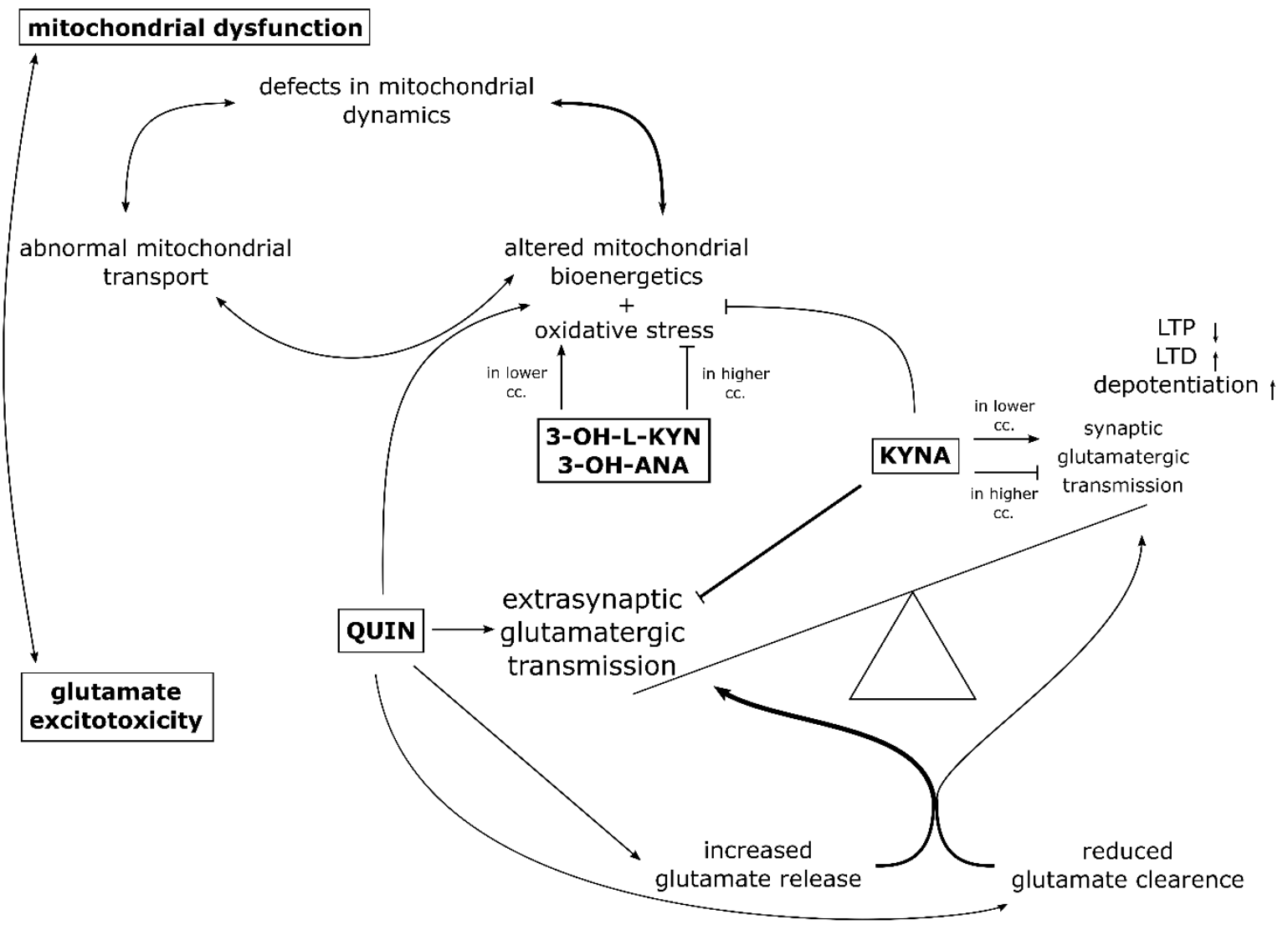

Figure 2 


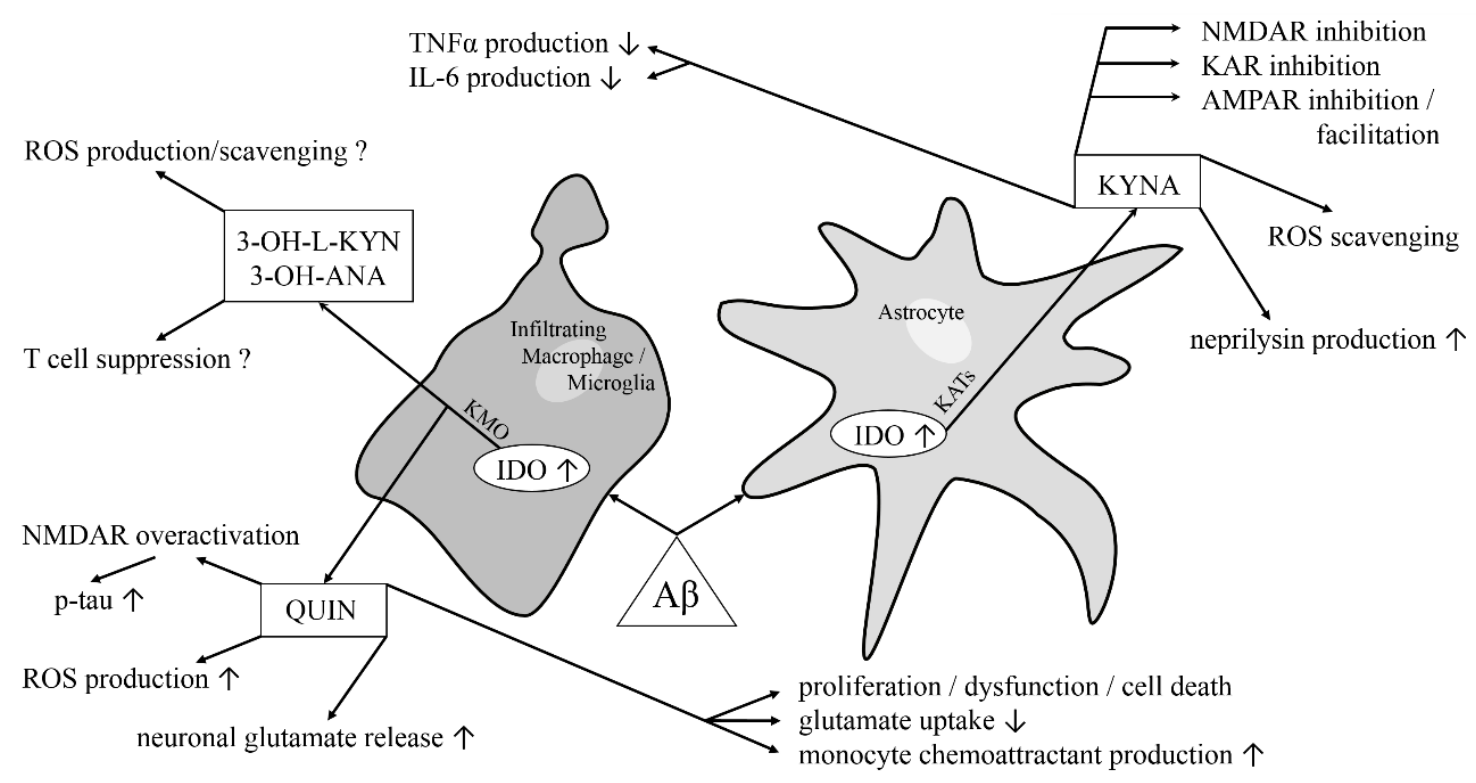

Figure 3 